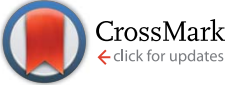

Cite this: RSC Adv., 2017, 7, 4855
Received 29th November 2016 Accepted 31st December 2016

DOI: $10.1039 / c 6 r a 27509 e$

www.rsc.org/advances

\section{Syntheses, structures, luminescent and photocatalytic properties of various polymers based on a "V"-shaped dicarboxylic acid $\dagger$}

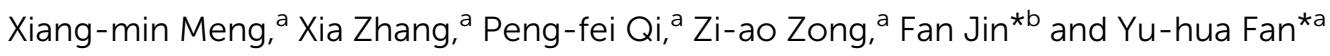

Solvothermal reactions of " $V$ "-shaped 3,5-di(4'-carboxyl-phenyl)benzene acid $\left(\mathrm{H}_{2} \mathrm{dpb}\right)$, and $\mathrm{Cd}(\mathrm{II}) / \mathrm{Zn}(\mathrm{I})$ salts in the presence of four ancillary bridging imidazole linkers afford four novel luminescent coordination polymers (LCPs), namely, $\left\{\left[\mathrm{Cd}(\mathrm{dpb})_{2}(\mathrm{bimb})_{2}\right] \cdot 0.5 \mathrm{H}_{2} \mathrm{O}\right\}_{n}(1),[\mathrm{Cd}(\mathrm{dpb})(\mathrm{tib})]_{n}(2),\left[\mathrm{Zn}(\mathrm{Hdpb})_{2}\left(4,4^{\prime}-\mathrm{bibp}\right)\right]_{n}(3)$ and $[\mathrm{Cd}(\mathrm{dpb})(1,3-\mathrm{bitl})]_{n}(4),($ bimb $=1,4$-bis(imidazol-1-ylmethyl)benzene, tib = 1,3,5-tris(1-imidazolyl) benzene, 4,4'-bibp = 4,4'-bis(imidazol-1-yl)biphenyl and 1,3-bitl = 1,3-bis(1-imidazoly)toluene). Then complexes 1-4 are characterized by elemental analysis, IR spectroscopy, powder X-ray diffraction (PXRD), thermogravimetric (TG) analysis and single-crystal $X$-ray diffraction. Single-crystal $X$-ray diffraction analysis shows that complex 1 shows an unprecedented 3-nodal $(2,2,4)$-connected 2D $+2 D$ $\rightarrow$ 3D two-fold interpenetration framework with the Schläfli symbol $\left(12^{5} \cdot 16\right)(12)^{2}$. Complexes 2 and 3 show a 2D layer structure and 1D zigzag chain, which are further assembled into a 3D supramolecular structure by $\pi \cdots \pi$ interactions and $\mathrm{H}$-bonds, respectively. While complex 4 displays a 3 -nodal $(2,2,8)$ connected network with a $-\mathrm{ABAB}-$ fashion. The luminescent recognition properties of polymers $1-4$ to metal cations and anions have also been explored systematically. The results demonstrate that 2 and 3 display highly sensitive and selective luminescence sensing towards $\mathrm{Fe}^{3+}$ ions, and 4 displays highly sensitive and selective luminescence sensing towards $\mathrm{Cu}^{2+}$ ions. 1-4 can work as highly sensitive sensors to $\mathrm{Cr}_{2} \mathrm{O}_{7}^{2-}$ by luminescence quenching. Moreover, the photocatalytic properties of four $\mathrm{Cd}(\Perp) /$ Zn(I) compounds (complex 1-4) have also been investigated.
\end{abstract}

\section{Introduction}

During the past decades, the construction of luminescent coordination polymers (LCPs) has attracted considerable attention not only for their potential applications in luminescence, ${ }^{1}$ catalysis, ${ }^{2}$ magnetism, ${ }^{3}$ gas storage,${ }^{4}$ separation, ${ }^{5}$ proton conduction, ${ }^{6}$ nonlinear optics ${ }^{7}$ and so on, but also for their aesthetically pleasing structures and diversities in topology. ${ }^{8}$ In particular, based on their great physical and chemical characteristics, their capability of detecting heavy metal ions plays a significant role in public health, ${ }^{9}$ environmental protection ${ }^{10}$ and medicinal science. ${ }^{11}$ For example, Wang's group has reported that Cd-based LCPs were assembled using aromatic hexa-carboxylate which shows high sensitivity to $\mathrm{Fe}^{3+}$ ions in waste-water. ${ }^{12}$ The Eu-MOF reported by Zhu's group can detect

${ }^{a}$ Key Laboratory of Marine Chemistry Theory and Technology, Ministry of Education, College of Chemistry and Chemical Engineering, Ocean University of China, Qingdao, Shandong 266100, P. R. China. E-mail: fanyuhua304@163.com

${ }^{b}$ Max Planck Institute for Terrestrial Microbiology \& LOEWE Center for Synthetic Microbiology(SYNMIKRO), Marburg, Germany. E-mail: pkujinfan@gmail.com

† Electronic supplementary information (ESI) available. CCDC 1061113, 1402587, 1430347 and 1479858. For ESI and crystallographic data in CIF or other electronic format see DOI: 10.1039/c6ra27509e
$\mathrm{Cu}^{2+}$ ions. ${ }^{13}$ Liu synthesized a $\mathrm{NH}_{2}-\mathrm{Zn}-\mathrm{MOF}$ that can detect $\mathrm{Cr}(\mathrm{III})$ and $\mathrm{Cr}(\mathrm{IV})$ which could cause water pollution. ${ }^{\mathbf{1 4}}$ Meanwhile, the photocatalytic capability of the $\mathrm{Zn} / \mathrm{Cd}$-based CPs which are constructed using V-shaped ligands, has received wide attention from the viewpoint of chemists. ${ }^{15}$ However, the LCPs sensors for detecting metal ions which assemble using Vshaped ligands are still quite few.

As we known, the aromatic multicarboxylate ligands play an important role in tuning the coordination framework structures due to their abundant coordination modes. Furthermore, due to their bent backbones and versatile bridging fashions, Vshaped aromatic multicarboxylate ligands are excellent candidates for building highly connected, interpenetrating, or helical coordination frameworks. ${ }^{16,17}$ Compared with some other reported V-shaped ligands (4-bpah, ${ }^{15 a} 4-$ bpab $^{15 b}$ and 2,4'-bpdc ${ }^{17 b}$ ), the V-shaped $\mathrm{H}_{2} \mathrm{dpb}$ we selected could show more advantages: (1) the $\mathrm{H}_{2} \mathrm{dpb}$ ligand with high solubility is easy to synthesize; (2) the suitable size makes it a reasonable candidate to generate LCPs with open frameworks; (3) the reports on LCPs assembled by V-shaped aromatic multicarboxylate ligands are rare; (4) the free rotation of two carboxylic benzene ring can promote the flexibility of the $\mathrm{H}_{2} \mathrm{dpb}$ ligand to meet the requirements of coordination geometries of metal ions; (5) the carboxylic group could show more coordination modes while coordinating to 

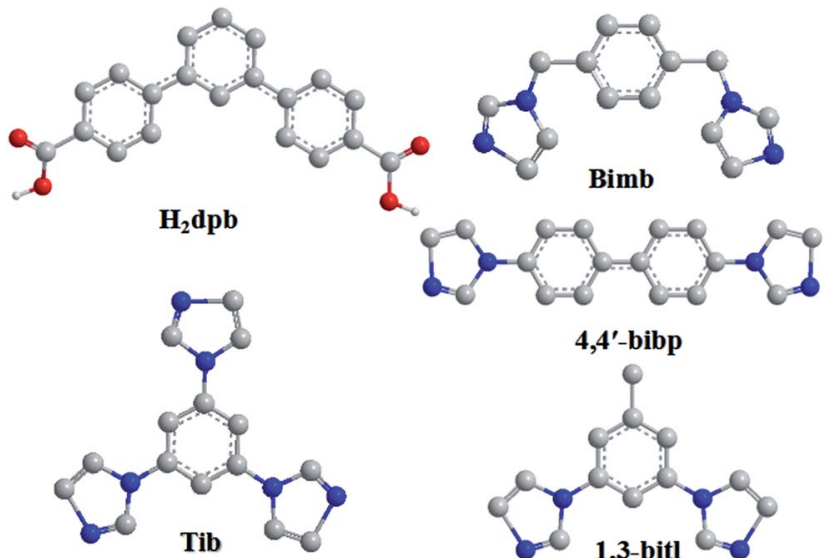

Til

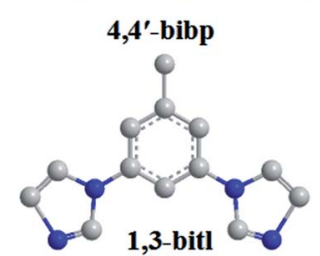

Scheme 1 Structures of $\mathrm{H}_{2} \mathrm{dpb}$ and four auxiliary $\mathrm{N}$-donor bridging linkers.

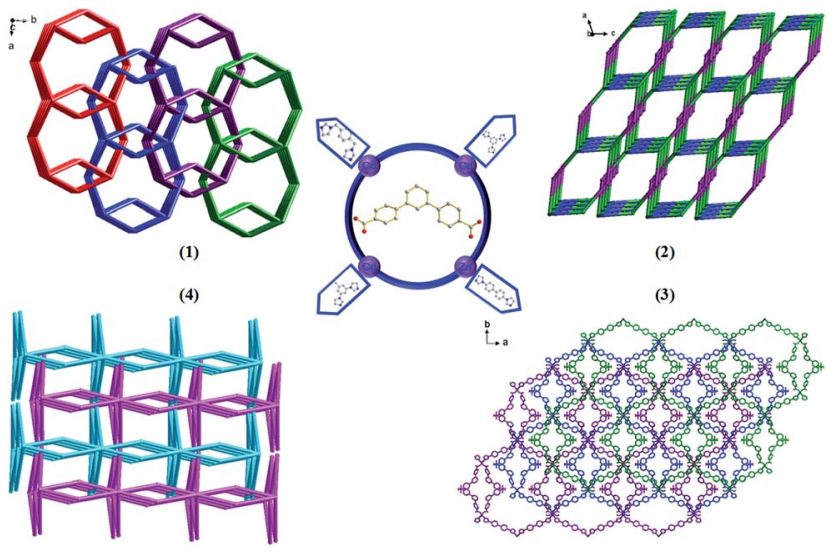

Scheme 2 Various polymeric structures of complexes 1-4.

metal ions. Meanwhile, to further investigate the influence of auxiliary N-donor ligands on the formation of final architectures, a series of semi-rigid/rigid imidazole ligands with different conformations were into the system (Scheme 1).

Herein, four mixed-ligand LCPs have been successfully synthesized under solvothermal conditions, namely, $\left\{\left[\mathrm{Cd}(\mathrm{dpb})_{2}(\mathrm{bimb})_{2}\right] \cdot 0.5 \mathrm{H}_{2} \mathrm{O}\right\}_{n} \quad(\mathbf{1}), \quad[\mathrm{Cd}(\mathrm{dpb})(\mathrm{tib})]_{n} \quad(2)$, $\left[\mathrm{Zn}(\mathrm{Hdpb})_{2}\left(4,4^{\prime} \text {-bibp }\right)\right]_{n}$ (3) and $[\mathrm{Cd}(\mathrm{dpb})(1,3-\mathrm{bitl})]_{n}$ (4), which show a systematic variation of architectures from $1 \mathrm{D}$ chain based on supramolecular to 3D interpenetrated framework (Scheme 2). The packing structures of these four complexes show that the nature of the bridging $\mathrm{N}$-donor linkers has a significant effect on the $\mathrm{H}_{2} \mathrm{dpb}$ coordination modes. Moreover, the luminescent recognition properties of metal cations/ anions and photocatalytic activities of the four $\mathrm{Cd}$ (II)/Zn(II) compounds were also investigated.

\section{Experimental section}

\section{Materials and physical measurements}

All reagents and solvents were purchased from Jinan Henghua Sci. \& Tec. Co. Ltd. and were used without further purification.
Infrared spectrum was recorded as $\mathrm{KBr}$ pellets on the Nicolet 170SX spectrometer in the $4000-400 \mathrm{~cm}^{-1}$ region. Elemental analysis (C, H, and N) was performed in a model 2400 PerkinElmer analyzer. Thermogravimetric analyses (TGA) were measured on a Perkin-Elmer TGA-7 thermogravimetric analyzer under air conditions from room temperature to $800{ }^{\circ} \mathrm{C}$ with a heating rate of $10{ }^{\circ} \mathrm{C} \mathrm{min}-1$. The X-ray powder diffractions (XRPD) were collected on an Enraf-Nonius CAD-4 X-ray singlecrystal diffractometer with $\mathrm{Cu}-\mathrm{K} \alpha$ radiation. Topological analysis were performed and confirmed by the Topos program and the Systre software. ${ }^{18,19}$

\section{Synthesis of $\left\{\left[\mathrm{Cd}(\mathrm{dpb})_{2}(\mathrm{bimb})_{2}\right] \cdot 0.5 \mathrm{H}_{2} \mathrm{O}\right\}_{n}(1)$}

A mixture of $\mathrm{H}_{2} \mathrm{dpb}(0.20 \mathrm{mmol}, 0.064 \mathrm{~g})$, bimb $(0.20 \mathrm{mmol}$, $0.048 \mathrm{~g}), \mathrm{Cd}\left(\mathrm{NO}_{3}\right)_{2} \cdot 4 \mathrm{H}_{2} \mathrm{O}(0.20 \mathrm{mmol}, 0.062 \mathrm{~g})$ and $8 \mathrm{~mL}$ of $\mathrm{DMF}-\mathrm{H}_{2} \mathrm{O}(\mathrm{v} / \mathrm{v}=1: 1)$ were placed in a Teflon-lined stainless steel vessel, heated to $120{ }^{\circ} \mathrm{C}$ for 3 days, and then cooled (a descent rate of $5{ }^{\circ} \mathrm{C} \mathrm{h}^{-1}$ ) to room temperature. Colourless block crystals of 1 were obtained. Yield of 51\% (based on Cd). Anal. (\%) calcd. for $\mathrm{C}_{34} \mathrm{H}_{26} \mathrm{CdN}_{4} \mathrm{O}_{4.5}$ : C, 60.41; H, 4.03; N, 8.29. Found: C, 60.31; H, 3.91; N, 8.31. IR (KBr pellet, $\mathrm{cm}^{-1}$ ): 3588 (m), 3170 (m), 1625 (s), 1550 (m), 1370 (vs), 1100 (m), 855 (m), 791 (m) $659(\mathrm{w})$.

\section{Synthesis of $[\mathrm{Cd}(\mathrm{dpb})(\mathrm{tib})]_{n}(2)$}

A mixture of $\mathrm{H}_{2} \mathrm{dpb}(0.20 \mathrm{mmol}, 0.064 \mathrm{~g})$, tib $(0.20 \mathrm{mmol}, 0.056$ $\mathrm{g}), \mathrm{Cd}\left(\mathrm{NO}_{3}\right)_{2} \cdot 4 \mathrm{H}_{2} \mathrm{O}(0.20 \mathrm{mmol}, 0.062 \mathrm{~g}), \mathrm{NaOH}(0.40 \mathrm{mmol}$, $0.016 \mathrm{~g})$ and $8 \mathrm{~mL}$ of water was placed in a Teflon-lined stainless steel vessel, heated to $150{ }^{\circ} \mathrm{C}$ for 3 days, and then cooled (a descent rate of $5{ }^{\circ} \mathrm{C} \mathrm{h}^{-1}$ ) to room temperature. Colourless block crystals of 2 were obtained. Yield of $60 \%$ (based on Cd). Anal. (\%) calcd. for $\mathrm{C}_{35} \mathrm{H}_{24} \mathrm{CdN}_{6} \mathrm{O}_{4}$ : C, 59.63; H, 3.43; $\mathrm{N}, 11.92$. Found: C, 59.51; H, 3.32; N, 11.64. IR (KBr pellet, $\mathrm{cm}^{-1}$ ): $3126(\mathrm{~s}), 1653(\mathrm{~m}), 1506(\mathrm{~s}), 1401(\mathrm{vs}), 1244(\mathrm{~m}), 775(\mathrm{~m})$, $669(\mathrm{~m})$.

\section{Synthesis of $\left[\mathrm{Zn}(\mathrm{Hdpb})_{2}\left(4,4^{\prime}-\text {-bibp }\right)\right]_{n}(3)$}

Complex 3 was synthesized following the same synthetic procedure as that for complex 2 except that $4,4^{\prime}$-bibp was used instead of tib and $\mathrm{Cd}\left(\mathrm{NO}_{3}\right)_{2} \cdot 4 \mathrm{H}_{2} \mathrm{O}$ was instead by $\mathrm{Zn}\left(\mathrm{NO}_{3}\right)_{2^{-}}$ $\cdot 6 \mathrm{H}_{2} \mathrm{O}$. Pink block crystals of 3 were obtained. Yield of $51 \%$ (based on Zn). Anal. (\%) calcd. for $\mathrm{C}_{58} \mathrm{H}_{40} \mathrm{ZnN}_{4} \mathrm{O}_{8}: \mathrm{C}, 70.62 ; \mathrm{H}$, 4.09; N, 5.68. Found: C, 70.46; H, 4.02; N, 5.56. IR (KBr pellet, $\mathrm{cm}^{-1}$ ): $3146(\mathrm{~m}), 1721$ (s), 1608 (s), 1554 (s), 1405 (vs), $1310(\mathrm{~m})$, $824(\mathrm{~m}), 774(\mathrm{~s})$.

\section{Synthesis of $[\mathrm{Cd}(\mathrm{dpb})(1,3-\mathrm{bit})]_{n}(4)$}

Complex 4 was synthesized following the same synthetic procedure as that for complex 1 except that 1,3-bitl was used instead of bimb. Colourless block crystals of 4 were obtained. Yield of $48 \%$ (based on Cd). Anal. (\%) calcd. for $\mathrm{C}_{33} \mathrm{H}_{24} \mathrm{CdN}_{4} \mathrm{O}_{4}$ : C, $60.70 ; \mathrm{H}, 3.70 ; \mathrm{N}, 8.58$. Found: C, 60.56; H, 3.62; N, 8.55. IR (KBr pellet, $\mathrm{cm}^{-1}$ ): 3125 (s), $1590(\mathrm{~m}), 1506$ (s), 1398 (vs), 1247 (w), $859(\mathrm{~m}), 771(\mathrm{~m})$. 
Table 1 Summary of crystal data and structure refinement parameters for $1-4^{a}$

\begin{tabular}{|c|c|c|c|c|}
\hline Compound & 1 & 2 & 3 & 4 \\
\hline Empirical formula & $\mathrm{C}_{34} \mathrm{H}_{27} \mathrm{CdN}_{4} \mathrm{O}_{4.5}$ & $\mathrm{C}_{35} \mathrm{H}_{24} \mathrm{CdN}_{6} \mathrm{O}_{4}$ & $\mathrm{C}_{58} \mathrm{H}_{40} \mathrm{~N}_{4} \mathrm{O}_{8} \mathrm{Zn}$ & $\mathrm{C}_{33} \mathrm{H}_{24} \mathrm{CdN}_{4} \mathrm{O}_{4}$ \\
\hline Formula weight & 676.00 & 705.00 & 986.31 & 652.96 \\
\hline Crystal system & Orthorhombic & Monoclinic & Monoclinic & Monoclinic \\
\hline Space group & $I 2_{1} 2_{1} 2_{1}$ & $P 2_{1} / c$ & $C 2 / c$ & $P 2 / c$ \\
\hline$a(\AA)$ & $14.0719(13)$ & $17.3405(15)$ & $32.919(3)$ & 17.7764(15) \\
\hline$b(\AA)$ & 21.6271(19) & $13.6821(11)$ & $6.8673(5)$ & 13.6685(12) \\
\hline$c(\AA)$ & $9.9750(9)$ & $25.213(2)$ & 21.6901(19) & $15.2008(13)$ \\
\hline$\alpha\left(^{\circ}\right)$ & 90 & 90 & 90 & 90 \\
\hline$\beta\left(^{\circ}\right)$ & 90 & $109.982(2)$ & $114.515(2)$ & $102.863(2)$ \\
\hline$\gamma\left(\left(^{\circ}\right)\right.$ & 90 & 90 & 90 & 90 \\
\hline$V\left(\AA^{3}\right)$ & $3035.7(5)$ & $5621.9(8)$ & $4461.4(6)$ & $3600.8(5)$ \\
\hline$Z$ & 4 & 4 & 4 & 4 \\
\hline$D_{\text {calcd }}\left(\mathrm{Mg} \mathrm{m}^{-3}\right)$ & 1.479 & 0.833 & 1.468 & 1.204 \\
\hline$\mu\left(\mathrm{mm}^{-1}\right)$ & 0.766 & 0.416 & 0.618 & 0.642 \\
\hline Reflections collected & 7612 & 27885 & 10537 & 17884 \\
\hline Data/parameters & $2697 / 201$ & $9891 / 597$ & $3913 / 321$ & $6336 / 507$ \\
\hline$F(000)$ & 1372 & 1424 & 2040 & 1320 \\
\hline$T(\mathrm{~K})$ & $298(2)$ & $298(2)$ & $298(2)$ & $298(2)$ \\
\hline$R_{\mathrm{int}}$ & 0.0750 & 0.0634 & 0.0460 & 0.0674 \\
\hline Final $R$ indices $[I>2 \sigma(I)]$ & $\begin{array}{l}R_{1}=0.0470 \\
\mathrm{w} R_{2}=0.0929\end{array}$ & $\begin{array}{l}R_{1}=0.0550 \\
\mathrm{w} R_{2}=0.1251\end{array}$ & $\begin{array}{l}R_{1}=0.0438 \\
\mathrm{w} R_{2}=0.0952\end{array}$ & $\begin{array}{l}R_{1}=0.0764 \\
\mathrm{w} R_{2}=0.2214\end{array}$ \\
\hline$R$ indices (all data) & $\begin{array}{l}R_{1}=0.0742 \\
\mathrm{w} R_{2}=0.1013\end{array}$ & $\begin{array}{l}R_{1}=0.1063 \\
\mathrm{w} R_{2}=0.1338\end{array}$ & $\begin{array}{l}R_{1}=0.0819 \\
\mathrm{w} R_{2}=0.1080\end{array}$ & $\begin{array}{l}R_{1}=0.1115 \\
\mathrm{w} R_{2}=0.2346\end{array}$ \\
\hline Gof & 1.062 & 1.059 & 1.026 & 1.096 \\
\hline
\end{tabular}

\section{X-ray crystallography}

X-ray crystallography data of complexes 1-4 were collected on a Bruker Apex Smart CCD diffractometer at 293(2) K with graphite-monochromatized Mo-K $\alpha$ radiation $(\lambda=0.71073 \AA)$ by using the $\omega-2 \theta$ scan mode. The structure was solved by direct methods using SHELXS-97. ${ }^{20}$ The non-hydrogen atoms were defined by the Fourier synthesis method. Positional and thermal parameters were refined by the full matrix least-squares method (on $F^{2}$ ) to convergence. ${ }^{21}$ Crystallographic data for complexes 1-4 are given in Table 1 . Selected bond lengths and angles for 1-4 are listed in Table S1. $\dagger$ CCDC numbers for complexes of 1-4 are 1430347 for 1, 1402587 for 2, 1061113 for 3 and 1479858 for 4 .

\section{Results and discussion}

\section{Synthesis and characterization}

The crystals of complexes 1-4 is dependent on the experimental method and the nitrate salts of $\mathrm{Cd}\left(\mathrm{NO}_{3}\right)_{2} \cdot 4 \mathrm{H}_{2} \mathrm{O}$ and $\mathrm{Zn}\left(\mathrm{NO}_{3}\right)_{2}$ $\cdot 6 \mathrm{H}_{2} \mathrm{O}$. Then suitable crystal were characterized by singlecrystal X-ray diffraction after cooling to room temperature. Those complexes 1-4 are stable in the solid state even after extended exposure to air. Meanwhile, all of the complexes 1-4 have poor solubility in water and common organic solvent, but can be slightly soluble in very high polarity solvents.

The IR spectra of complexes 1-4 display characteristic absorption bands of the coordinated carboxylate groups appear at $1590-1653 \mathrm{~cm}^{-1}$ for asymmetric stretching and 1320-1401 $\mathrm{cm}^{-1}$ for the symmetric. ${ }^{22}$ Meanwhile, a adsorption bands are observed in ca. $1721 \mathrm{~cm}^{-1},{ }^{23}$ suggesting the partially deprotonation of carboxylic groups in 3, which is consistent with the results of the X-ray diffraction analysis.

\section{Structure description of $\left\{\left[\mathrm{Cd}(\mathrm{dpb})_{2}(\mathrm{bimb})_{2}\right] \cdot 0.5 \mathrm{H}_{2} \mathrm{O}\right\}_{n}(1)$}

Single-crystal X-ray diffraction analysis reveals that 1 crystallizes in the orthorhombic system with space group I2(1)2(1)2(1). As can be seen from Fig. 1a, the asymmetric unit consists of one $\mathrm{Cd}(\mathrm{II})$ ion, two $\mathrm{dpb}^{2-}$ carboxylate ligands and two bimb $\mathrm{N}$-donor ligands. The $\mathrm{Cd}(\mathrm{II})$ is six-coordinated by four $\mathrm{O}$ atoms from two $\mathrm{dpb}^{2-}$ ligands $\left[\mathrm{Cd}(1)-\mathrm{O}(1)=\mathrm{Cd}(1)-\mathrm{O}(1)^{\# 1}=2.248(5) \AA\right.$, $\mathrm{Cd}(1)-$ $\left.\mathrm{O}(2)=\mathrm{Cd}(1)-\mathrm{O}(2)^{\# 1}=2.545(6) \AA\right]$ and two $\mathrm{N}$ atoms from two bimb bridging linkers $\left[\mathrm{Cd}(1)-\mathrm{N}(2)=\mathrm{Cd}(1)-\mathrm{N}(2)^{\# 1}=2.283(5) \AA\right]$, which adopts a distorted octahedral $\left\{\mathrm{CdN}_{2} \mathrm{O}_{4}\right\}$ coordination geometry.

As shown in Scheme 3, each "V"-shaped $\mathrm{dpb}^{2-}$ ligand coordinates with two adjacent $\mathrm{Cd}(\mathrm{II})$ ion by adopting a $\mu_{2}-\left(\kappa^{1}-\kappa^{1}\right)-\left(\kappa^{1}-\right.$ $\kappa^{1}$ ) coordination mode (Scheme 3 , Mode I) forming an infinite $1 \mathrm{D}[\mathrm{Cd}-\mathrm{dpb}]_{n}$ linear chain, in which the two carboxyl groups show same $\mu_{1}-\left(\kappa^{1}-\kappa^{1}\right)$ coordination. Interestingly, the $\mu_{2}$ bridging bimb ligands exhibits a "U" shape conformation to connect the adjacent $\mathrm{Cd}(\mathrm{II})$ ions to result in a single-strand helix chain $[\mathrm{Cd}-\mathrm{bimb}]_{n}$ with the Cd $\cdots \mathrm{Cd}$ separation of $12.86 \AA$. The two types of $1 \mathrm{D}$ chains $\left([\mathrm{Cd}-\mathrm{dpb}]_{n}\right.$ and $\left.[\mathrm{Cd}-\mathrm{bimb}]_{n}\right)$ are alternatively connected with each other, constructing a 2D network (Fig. 1b). The two adjacent 2D networks are further interact with each other through helix chain $\left([\mathrm{Cd}-\mathrm{bimb}]_{n}\right)$ twining round the "V"-shaped $\mathrm{H}_{2}$ dpb ligands, finally resulting in a rarely $2 \mathrm{D}+2 \mathrm{D}$ $\rightarrow$ 3D two-fold interpenetration parallel framework (Fig. 1c). The effective free volume of 1 was $10.5 \%$ of the crystal volume 
a)

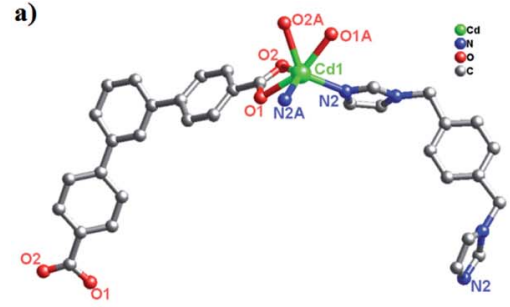

b)
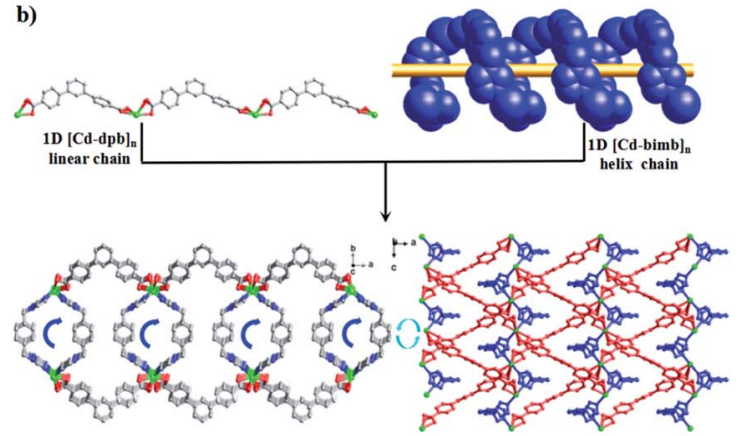

c)
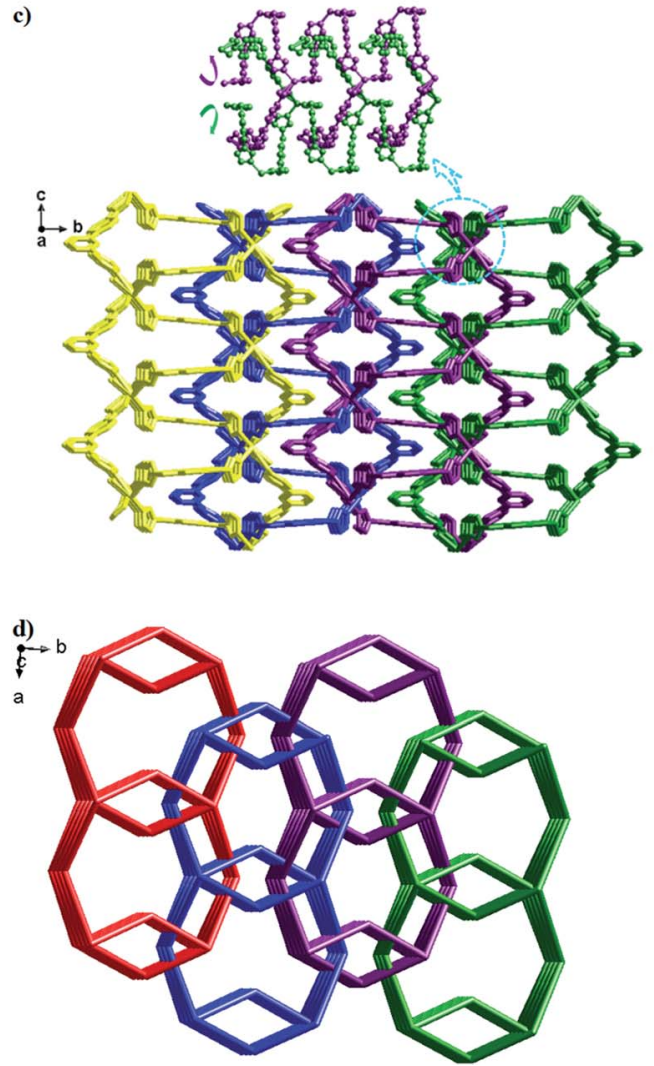

Fig. 1 (a) Coordination environment of the $\mathrm{Cd}(\mathrm{I})$ ion in complex 1 (symmetry codes: (A) $-x+3 / 2, y+0,-z+1$; (B) $-x+1 / 2, y+0,-z+2$; (C) $x,-y+2,-z+1 / 2)$. (b) View of the 1D [Cd-dpb $]_{n}$ linear chain, 1D [Cdbimb $]_{n}$ helical chain and 2D network of 1 (blue spheres: bimb ligands; red spheres: $\mathrm{dpb}^{2-}$ ligands). (c) The 2D $+2 \mathrm{D} \rightarrow 3 \mathrm{D}$ two-fold interpenetration parallel networks viewed along the a axis. (d) The 2D $+2 \mathrm{D} \rightarrow 3 \mathrm{D}$ interpenetrated $(2,2,4)$-connected topology $\left(12^{5} \cdot 16\right)(12)^{2}$ sheets in 1.
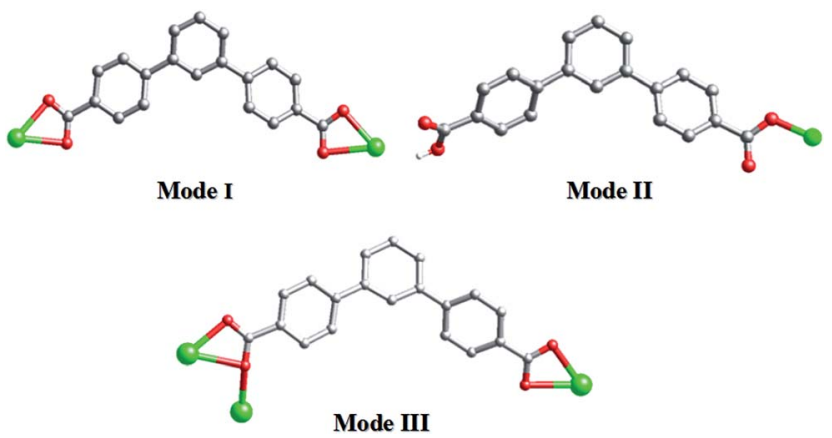

Scheme 3 Diverse coordination modes of $\mathrm{H}_{2} \mathrm{dpb}$ in complexes 1-4.

(318.7 out of the $3035.7 \AA^{3}$ unit cell volumes), calculated by PLATON analysis. ${ }^{24}$

From the viewpoint of structural topology, the Cd(II) ions are coordinated by two $\mathrm{dpb}^{2-}$ ligands and two bimb ligands, which can be viewed as a 4-connected node and the $\mathrm{dpb}^{2-}$ ligand as a "V"-shaped spacer, then an unprecedented 3-nodal $(2,2,4)$ connected 3D interpenetrated framework is created with $\left(12^{5} \cdot 16\right)(12)^{2}$ topology (Fig. 1d).

\section{Structure description of $[\mathrm{Cd}(\mathrm{dpb})(\mathrm{tib})]_{n}(2)$}

The crystal structure determined by single-crystal X-ray diffraction showed that complex 2 crystallizes in the monoclinic system, space group $P 2_{1} / c$. The asymmetric unit of 2 contains one $\mathrm{Cd}$ (II) cation, one $\mathrm{dpb}^{2-}$ ligand and one tib ligand. As shown in Fig. 2a, each $\mathrm{Cd}$ (II) cation with an unusual $\left\{\mathrm{CdN}_{3} \mathrm{O}_{4}\right\}$ distorted decahedral coordination geometry is sevencoordinated by three imidazolyl nitrogen atoms from three tib ligands $[\mathrm{Cd}-\mathrm{O}=2.320(3)-2.580(4) \AA]$, and four oxygen atoms from two $\mathrm{dpb}^{2-}$ anions $\left[\mathrm{Cd}(1)-\mathrm{N}(2)=2.322(4) \AA, \mathrm{Cd}(1)-\mathrm{N}(4)^{\# 1}=\right.$ $2.306(4) \AA$ and $\mathrm{Cd}(1)-\mathrm{N}(5)=2.326(4) \AA]$. Cd to O/N distances and bond angles are within the normal range.

In complex 2 , the completely deprotonated $\mathrm{dpb}^{2-}$ ligand exhibits a $\mu_{2}-\left(\kappa^{1}-\kappa^{1}\right)-\left(\kappa^{1}-\kappa^{1}\right)$ coordination mode (Scheme 3 , Mode I). Two neighbour Cd(II) cation were connected by "V"-shaped $\mathrm{dpb}^{2-}$ ligand form a $1 \mathrm{D}\left[\mathrm{Cd}^{-\mathrm{dpb}^{2-}}\right]_{n}$ chain with the $\mathrm{Cd} \cdots \mathrm{Cd}$ separation is $17.625 \AA$, and tib ligand form a $1 \mathrm{D}[\mathrm{Cd}-\mathrm{tib}]_{n}$ ladder shaped chain with different $\mathrm{Cd} \cdots$ Cd separation $(10.573,11.411$ and $13.682 \AA$ Å), respectively. Each ladder-like chain contains two types of binuclear $\left(\left\{\mathrm{Cd}_{2} \mathrm{~N}_{8} \mathrm{C}_{10}\right\}\right.$ 20-membered ring and $\left\{\mathrm{Cd}_{2} \mathrm{~N}_{8} \mathrm{C}_{12}\right\}$ 22-membered ring) loops. The adjacent $1 \mathrm{D}$ chains are further intersected with each other by sharing the same Cd(II) cation, finally giving a 2D network (Fig. 2b). The final 3D supramolecular framework of complex 2 is through the $\mathrm{C}-\mathrm{H} \cdots \mathrm{C}$ between the carbon atoms from phenyl ring and imidazolyl $\left[\mathrm{C}\left(35^{\prime}\right)-\mathrm{H}\left(35^{\prime}\right) \cdots \mathrm{C}(6)=2.915 \AA\right]$ (Fig. $2 \mathrm{c}$ and S1 $\dagger$ ). Meanwhile, $\pi \cdots \pi$ stacking interactions make a more stable $3 \mathrm{D}$ supramolecular structure. Besides, the void volume of 2 is $44.3 \%$ of the crystal volume (2489.9 out of the $5621.9 \AA^{3}$ unit cell volume), calculated by PLATON.

From the viewpoint of topology, the "V"-liked $\mathrm{dpb}^{2-}$ anions can be defined as 2-connected nodes, while the tib ligands can be considered as 3-connected nodes. Thus the 3D 
a)
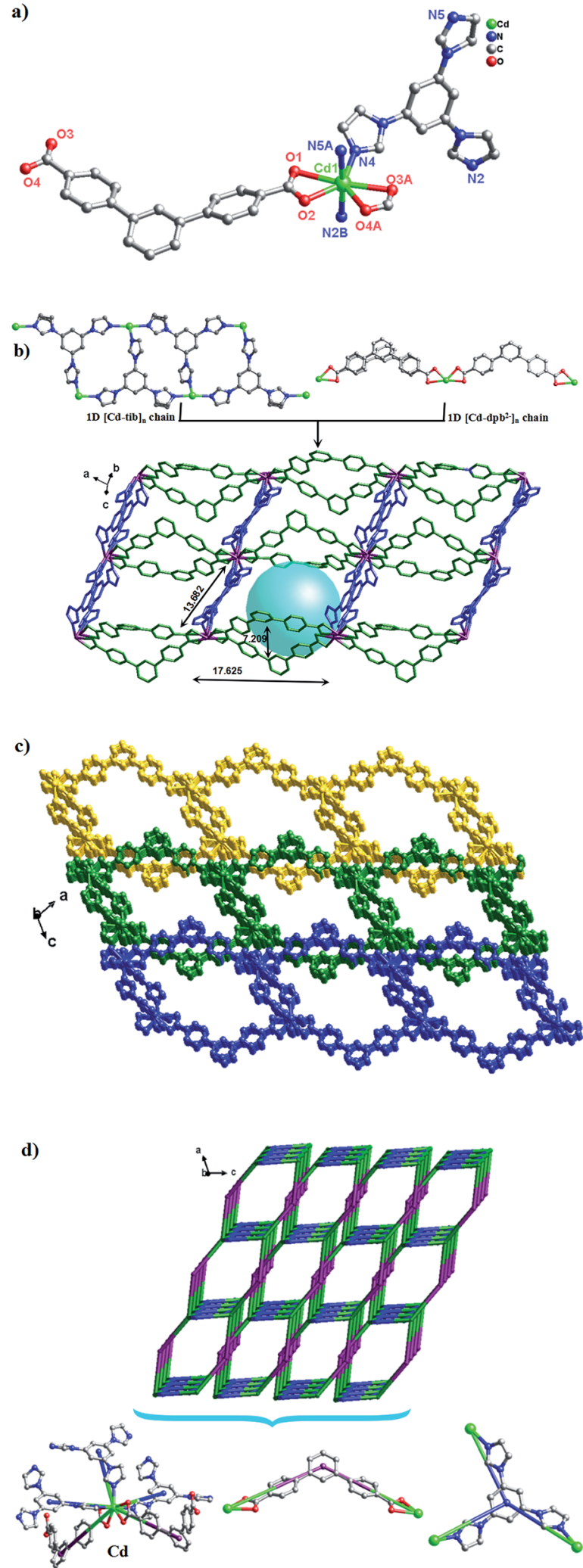

Fig. 2 (a) Coordination environment of the $\mathrm{Cd}(॥)$ ion in complex 2 (symmetry codes: (A) $-x+1,-y+1,-z+2$; (B) $x, y-1, z$; (C) $x, y+1, z$ ). Note: the dangling benzyl rings are omitted for clarity. (b) View of the $2 D$ network of 2 (blue spheres: tib ligands; green spheres: $\mathrm{dpb}^{2-}$ ligands). (c) The 2D $\rightarrow$ 3D supramolecular networks by $\mathrm{C}-\mathrm{H} \cdots \mathrm{C}$ and $\pi-\pi$ interactions. (d) Views of the $(2,3,5)$-connected 3D supramolecular frameworks with unprecedented $\left(4^{2} \cdot 6 \cdot 8^{6} \cdot 12\right)\left(4^{2} \cdot 6\right)(8)$ topology. supramolecular structure can be simplified as an unprecedented 3-nodal $(2,3,5)$-connected framework with the point Schläfli symbol $\left(4^{2} \cdot 6 \cdot 8^{6} \cdot 12\right)\left(4^{2} \cdot 6\right)(8)$ (Fig. 2d).

\section{Structure description of $\left[\mathrm{Zn}(\mathrm{Hdpb})_{2}\left(4,4^{\prime}-\text {-bibp }\right)\right]_{n}(3)$}

A similar reaction environment compared with complex 1 was used except for the $\mathrm{H}_{2} \mathrm{O}-\mathrm{CH}_{3} \mathrm{CN}$ system being replaced with the $\mathrm{H}_{2} \mathrm{O}$, results in a 3D supramolecular structure. Complex 3 crystallizes in monoclinic space group $C 2 / c$. The asymmetric unit of 3 contains one $\mathrm{Zn}(\mathrm{II})$ ion, two $\mathrm{Hdpb}^{-}$carboxylate ligands, and one 4, $4^{\prime}$-bibp N-donor ligand as shown in Fig. 3a. The Zn(1) center is a four-coordinated by two $\mathrm{O}$ atoms from two $\mathrm{Hdpb}^{-}$ ligands and two $\mathrm{N}$ atoms from two 4,4'-bibp ligands, displaying a distorted triangle cone geometry. The bond length of $\mathrm{Zn}-\mathrm{O}$ is 1.940(2) $\AA$, and the $\mathrm{Zn}-\mathrm{N}$ distance is 2.019(2) $\AA$, respectively. Both $\mathrm{Zn}-\mathrm{O}$ and $\mathrm{Zn}-\mathrm{N}$ bond length also well-matched to similar complexes. ${ }^{25}$

The two partially deprotonated carboxyl groups of "V"-liked $\mathrm{Hdpb}^{-}$ligands exhibit a $\mu_{1}-\left(\kappa^{1}-\kappa^{0}\right)$ coordination mode (Scheme 3, Mode II). Two adjacent "V"-liked $\mathrm{Hdpb}^{-}$ligands linked the same $\mathrm{Zn}$ (II) ions hold a limited helix chain, and the N-donor ligands linking two adjacent $\mathrm{Zn}$ (II) ions along the axis to form a 1D zigzag chain [Zn(bibp) $]_{n}$ (Fig. 3b). Such chains are linked through $\mathrm{O}-\mathrm{H} \cdots \mathrm{O}$ hydrogen bonds along $[1,1,0]$ orientation to form $3 \mathrm{D}$ cone supramolecular structure (Fig. $3 \mathrm{c}$ and $\mathrm{S} 2 \dagger$ ). The dihedral angle between the three phenyl rings in $\mathrm{Hdpb}^{-}$are $18.78(4)^{\circ}, 34.31(3)^{\circ}$ and $47.91(4)^{\circ}$ respectively.

\section{Structure description of $[\mathrm{Cd}(\mathrm{dpb})(1,3-\mathrm{bitl})]_{n}(4)$}

A similar reaction environment compared with complex 3 was used except for the bimb N-donor ligand being replaced by 1,3bitl, results in another 3D supramolecular ladder structure. Compound 4 crystallizes in the monoclinic space group $P 2 / c$. In the asymmetric unit, there exist one crystallographically unique $\mathrm{Cd}(\mathrm{II})$ ions, one $\mathrm{dpb}^{2-}$ carboxylate ligands and one coordinated 1,3-bitl N-donor ligand. As shown in Fig. 4a, each Cd(II) cation also show an unusual seven-coordinated by five $\mathrm{O}$ atoms from three individual $\mathrm{dpb}^{2-}$ carboxylate ligands $(\mathrm{Cd}-\mathrm{O}=2.316(6)-$ $2.622(6) \AA)$ and two N atoms from two different 1,3-bitl N-donor ligand $(\mathrm{Cd}-\mathrm{N}(2)=2.231(7)$ and $\mathrm{Cd}-\mathrm{N}(3)=2.314(8) \AA$ ) with a $\left\{\mathrm{CdN}_{2} \mathrm{O}_{5}\right\}$ coordination environment, displaying a slightly distorted decahedral geometry. Both $\mathrm{Cd}-\mathrm{O}$ and $\mathrm{Cd}-\mathrm{N}$ bond length also well-matched to similar complexes. ${ }^{26}$

In complex 4 , the completely deprotonated $\mathrm{dpb}^{2-}$ ligand exhibits a $\mu_{3}-\left(\kappa^{1}-\kappa^{2}\right)-\left(\kappa^{1}-\kappa^{1}\right)$ coordination mode (Scheme 3, Mode III). The dihedral angles between the three phenyl rings in $\mathrm{dpb}^{2-}$ are $35.78(2), 27.96(3)$ and $19.18(3)^{\circ}$, respectively. In the structure, two $\operatorname{Cd}(1)$ ions are connected by the $\mu_{2}-\left(\kappa^{1}-\kappa^{2}\right)$ carboxyl group, forming $\left\{\mathrm{Cd}_{2}(\mathrm{COO})_{2}\right\}$ SBUs, which can be viewed as a shared nodal. Meanwhile, the two adjacent $\left\{\mathrm{Cd}_{2}(\mathrm{COO})_{2}\right\}$ SBUs are connected by two "V"-shaped $\mathrm{dpb}^{2-}$ ligands forming a bigger $\left\{\mathrm{Cd}_{4}\left(\mathrm{dpb}^{2-}\right)_{2}\right\}$ (28-membered) ring and two bitl ligands forming a $\left\{\mathrm{Cd}_{4}(\mathrm{bitl})_{2}(\mathrm{COO})_{2}\right\}$ (26-membered) ring. Then the two different loops intersected with each other forming a stable $2 \mathrm{D}$ network with a 17.776(15) $\times 13.668(12) \times$ 6.1052(28) $\AA^{3}$ quadrilateral opening (Fig. $4 \mathrm{~b}$ ). The adjacent $2 \mathrm{D}$ 
a)

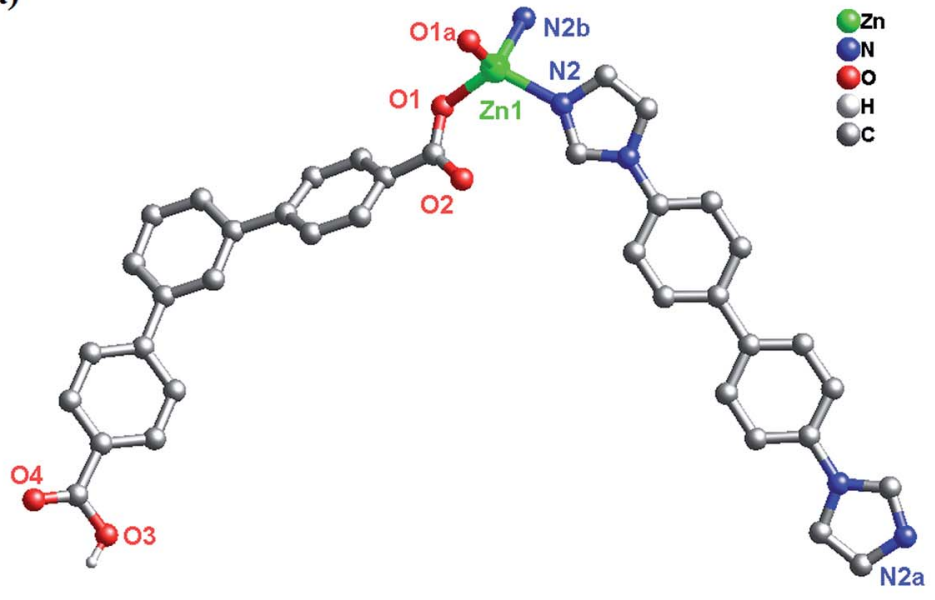

b)
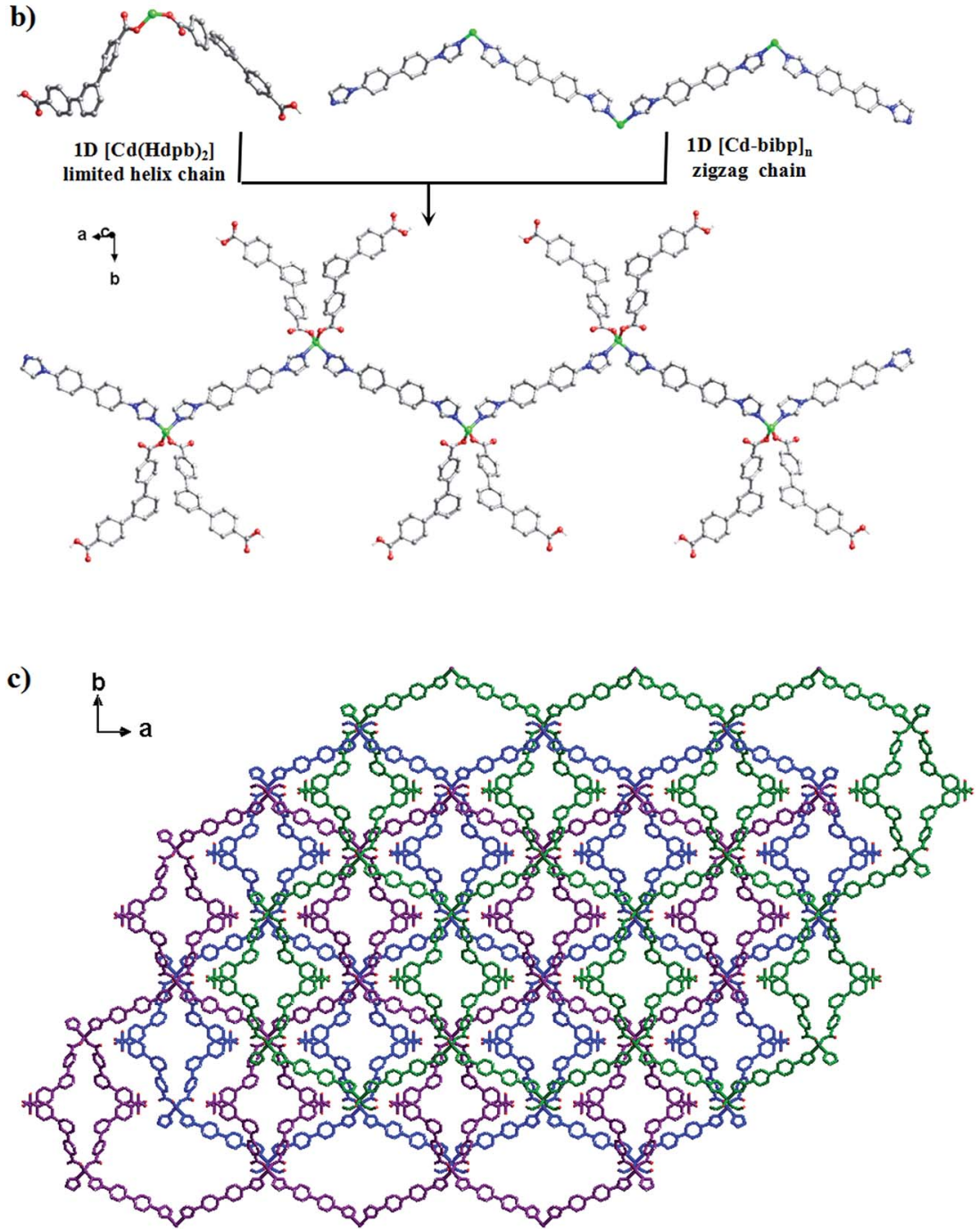

Fig. 3 (a) Coordination environment of the $Z n(I)$ ion in complex 3 (symmetry codes: (A) $-x+1, y,-z+3 / 2$; (B) $-x+3 / 2,-y+5 / 2,-z+2$ ). (b) The simplified 1D zigzag chain structure of along the a axis in complex 3. (c) From 1D chain to 3D supramolecular structure of complex 3, which are linked by $\mathrm{O}-\mathrm{H} \cdots \mathrm{O}$ hydrogen bonds along $[1,1,0]$ orientation. 
a)
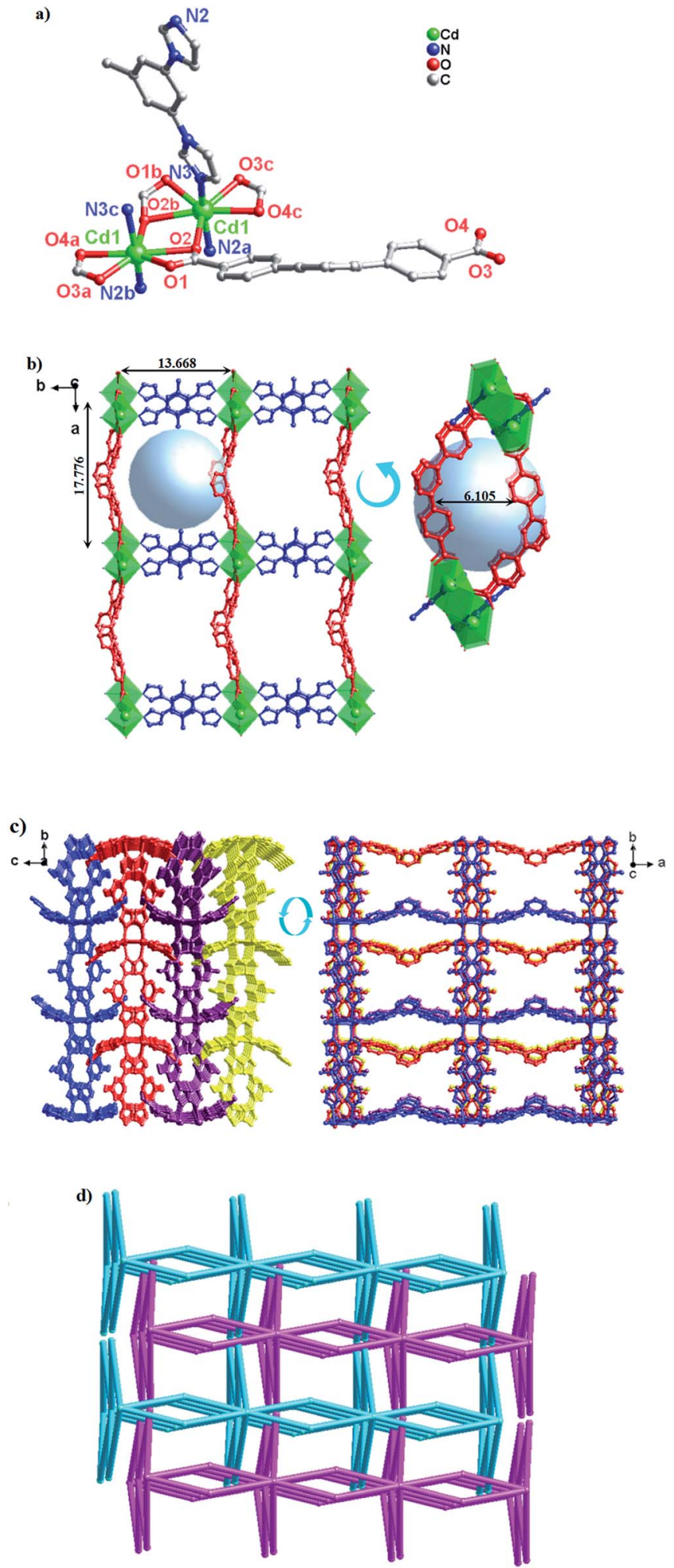

Fig. 4 (a) Coordination environment of the $\mathrm{Cd}(॥)$ ion in complex 4 (symmetry codes: (A) $-x+1, y,-z+3 / 2$; (B) $x, y+1, z$; (C) $x+1, y, z$; (D) $x-1, y, z$ ). Note: the dangling benzyl rings are omitted for clarity. (b) View of the 2D network of 4 (blue spheres: 1,3-bitl ligands; red spheres: $\mathrm{dpb}^{2-}$ ligands). Note: the dangling benzyl rings are omitted for clarity. (c) From 2D network to 3D framework of complex 4, which are linked by $\mathrm{C}-\mathrm{H} \cdots \mathrm{O}$ bonds along $[0,1,1]$ orientation. Note: the dangling benzyl rings are omitted for clarity. (d) Views of the $(2,2,8)$ connected $2 \mathrm{D} \rightarrow$ 3D network with a - ABAB - fashion. network are alternatively connected with each other through $\mathrm{C}-\mathrm{H} \cdots \mathrm{O}$ bonds (Table $\mathrm{S} 2, \uparrow \mathrm{C}(28)-\mathrm{H}(28) \cdots \mathrm{O}(3)=2.411$ and $\mathrm{C}(21)-\mathrm{H}(21) \cdots \mathrm{O}(3)=2.431 \AA)$, constructing a stable 3D network (Fig. $4 \mathrm{c}$ and S3†). The effective free volume of 4 was $22.9 \%$ of the crystal volume (823.0 out of the $3600.8 \AA^{3}$ unit cell volumes), calculated by PLATON analysis.

From the topologically, the $\left\{\mathrm{Cd}_{2}(\mathrm{COO})_{2}\right\}$ SBUs can be regarded as eight-connected nodes and "V"-shaped $\mathrm{dpb}^{2-}$ ligands as two-connected nodes; thus, this layer displays a 3-nodal $(2,2,8)$ connected network (Fig. $4 \mathrm{~d}$ ).

\section{Structural comparison and discussion}

The structures of LCPs have been found to be greatly influenced by N-donor ligands based on previous literature. As shown in Scheme 3 and Table $\mathrm{S} 3, \dagger \mathrm{H}_{2} \mathrm{dpb}$ exhibits versatile coordination modes, resulting in different new structures (1D-3D). In complexes 1 and 2, the "V"-shaped $\mathrm{dpb}^{2-}$ ligands chelate the metal atoms (chelate both in $\mathbf{1}$ and 2) through their two carboxylate groups, to further stabilize the 1D chain. After that, those chains further interacted with bimb (1D [Cd-bimb $]_{n}$ helix chain)/tib (1D [Cd-tib $]_{n}$ ladder chain) chain to form the final 2D $+2 \mathrm{D} \rightarrow 3 \mathrm{D}$ interpenetrated $(2,2,4)$-connected unprecedented and $(2,3,5)$-connected unprecedented $3 \mathrm{D} / 2 \mathrm{D}$ topologies. For complex 3, only one carboxylate group of the $\mathrm{H}_{2} \mathrm{dpb}$ ligand coordinated with the metal atoms (monodentate in 3), and the other carboxylate group interacted with the adjacent $\left[\mathrm{Zn}(\mathrm{Hdpb})_{2}\left(4,4^{\prime} \text {-bibp }\right)\right]_{n}$ chain to form the $3 \mathrm{D}$ supramolecular structure through H-bonding interactions. For 4, one carboxylate group of the $\mathrm{dpb}^{2-}$ adopt in $\mu_{2}-\left(\kappa^{1}-\kappa^{2}\right)$-chelate fashion and the other carboxylate group show $\mu_{2}-\left(\kappa^{1}-\kappa^{1}\right)$-chelate coordination modes. And each carboxylate group connecting neighboring $\mathrm{Cd}(\mathrm{II})$ atoms and 1,3-bitl $\mathrm{N}$-donor ligand to form the $2 \mathrm{D}$ network, which is further interacted by $\mathrm{C}-\mathrm{H} \cdots \mathrm{O}$ to form a 3D supramolecular structure. Moreover, $\mathrm{H}_{2} \mathrm{dpb}$ is completely deprotonated in 1, $\mathbf{2}$ and $\mathbf{4}$, and partly deprotonated $\left(\mathrm{Hdpb}^{-}\right)$in 3; their asymmetric units contain two $\mathrm{H}_{2} \mathrm{dpb}$ ligands in $\mathbf{1}$ and $\mathbf{3}$, and one $\mathrm{H}_{2}$ dpb ligand in 2 and 4. Meanwhile, the " $\mathrm{V}$ "-shaped ligand play important roles in the construction of bigger open spacer framework in $\mathbf{1}, \mathbf{2}$ and $\mathbf{4}$.

For N-donor ligands, the differences in their lengths and configurations greatly influence the final structure of the targeted CPs. Except $\mathbf{1}$ is a semi-flexible-auxiliary ligand, the Ndonor ligands can be seen as rigid-auxiliary ligand in complexes 2-4. Thus the complex 1 show a $2 \mathrm{D}+2 \mathrm{D} \rightarrow 3 \mathrm{D}$ twofold interpenetrated framework, and 3D supramolecular framework in $\mathbf{2 - 4}$, respectively. Due to the different configurations of the $\mathrm{N}$-donor ligands, complex 2 shows a higher effective free volume (44.3\%) than complexes 1 (10.5\%) and 4 (22.9\%). Hence, complex 2 may be a good candidate for application in gas/dye absorption.

\section{Thermal analyses}

To understand the thermal stabilities of compounds 1-4, their thermal behaviors were investigated by TGA (Fig. S4 $\dagger$ ). The experiments were performed on samples consisting of numerous single crystals of 1-4 under a $\mathrm{N}_{2}$ atmosphere with 

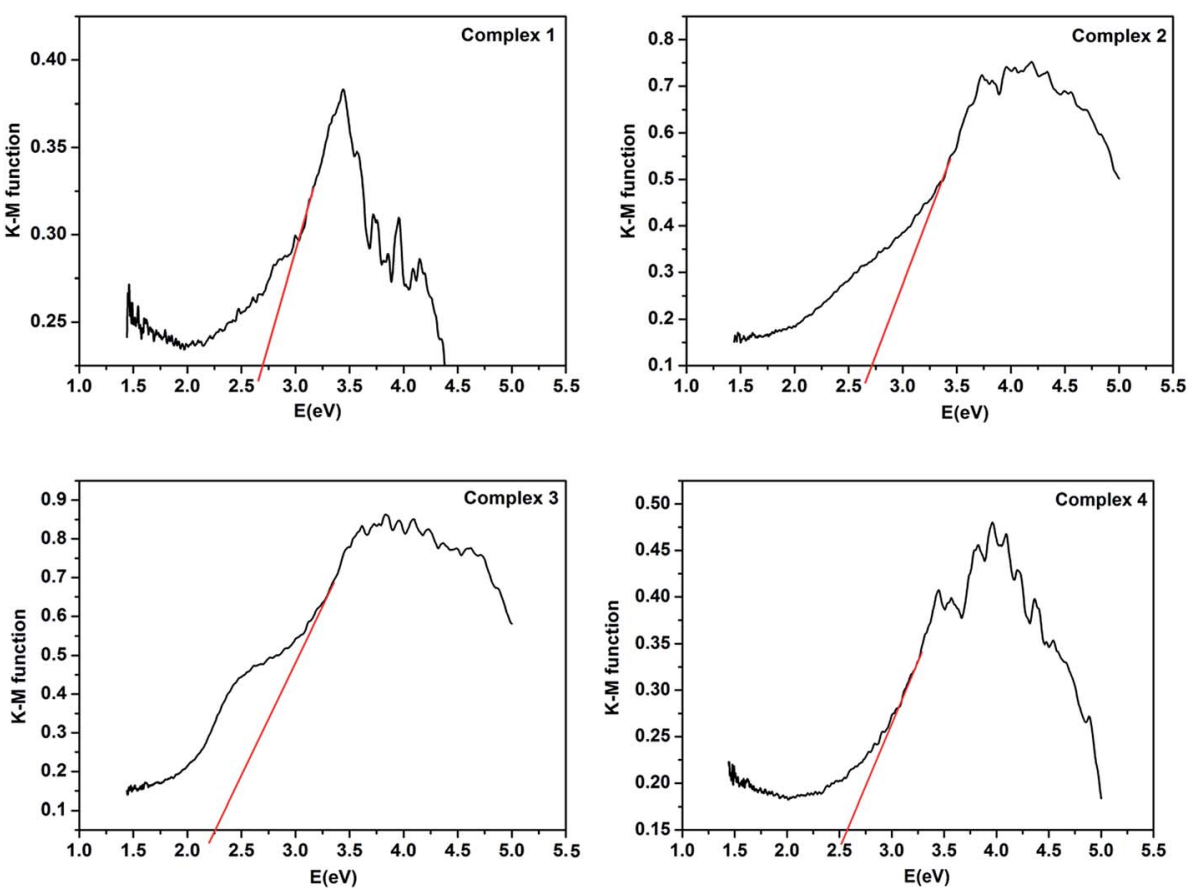

Fig. 5 Kubelka-Munk-transformed diffuse reflectance spectra of complexes 1-4.

a heating rate of $10{ }^{\circ} \mathrm{C} \min ^{-1}$. For complex 1 , the first weight loss in the temperature range of $80-150{ }^{\circ} \mathrm{C}$ is consistent with the removal of the lattice $\mathrm{H}_{2} \mathrm{O}$ (obsd: $1.1 \%$, calcd: $1.3 \%$ ). The second weight loss corresponds to the loss of the organic ligands at $c a$. $350{ }^{\circ} \mathrm{C}$. The remaining weight corresponds to the formation of CdO (obsd: $23.7 \%$, calcd: $19.1 \%$ ). For complex 2, the decomposition of the compound occurs at ca. $330{ }^{\circ} \mathrm{C}$, and the remaining weight corresponds to the formation of CdO (obsd: $33.1 \%$, calcd: $18.2 \%$ ). For complex 3 , the whole structure starts to collapse at $\mathrm{ca} .350{ }^{\circ} \mathrm{C}$ with a result of thermal decomposition and the remaining residue of $\mathrm{ZnO}$ (obsd: $30.2 \%$, calcd: $8.2 \%$ ). For complex 4, the destruction of the framework occurs at $c a$. $230{ }^{\circ} \mathrm{C}$, finally leading to the formation of the stoichiometric amount of CdO as a residue (obsd: $20.2 \%$, calcd: $19.8 \%$ ).

\section{Optical band gaps}

Because of the energy band gap $\left(E_{\mathrm{g}}\right)$ of CPs is closely related to its photocatalytic ability. Thus investigate the conductivity potentials of titled compounds are necessarily. And the band gap energy of CPs can be evaluated by Kubelka-Munk transformation $(F):{ }^{27} F=(1-R) / 2 R$, where transformed from the recorded diffuse reflectance data and $R$ is the reflectance of an infinitely thick layer at a given wavelength. ${ }^{28}$ As shown in Fig. 5, the $E_{\mathrm{g}}$ values assessed from the steep absorption edge for complexes 1-4 are 2.70, 2.74, 2.28 and $2.59 \mathrm{eV}$, respectively, which indicate that complexes $\mathbf{1 - 4}$ are potential semiconductive materials. ${ }^{29,30}$

\section{Luminescence properties}

The luminescence properties of complexes 1-4 together with the free $\mathrm{H}_{2} \mathrm{dpb}$, bimb, tib, 4,4'-bibp and 1,3-bitl ligands, were investigated in the solid state at ambient temperature (Table $\mathrm{S} 4 \dagger)$. The free ligands emit strong fluorescence centered at $405 \mathrm{~nm}\left(\lambda_{\mathrm{ex}}=275 \mathrm{~nm}\right)$ for $\mathrm{H}_{2} \mathrm{dpb}, 380 \mathrm{~nm}\left(\lambda_{\mathrm{ex}}=220 \mathrm{~nm}\right)$ for bimb, $371 \mathrm{~nm}\left(\lambda_{\text {ex }}=275 \mathrm{~nm}\right)$ for tib, $378 \mathrm{~nm}\left(\lambda_{\text {ex }}=270 \mathrm{~nm}\right)$ for 4,4'-bibp and $385 \mathrm{~nm}\left(\lambda_{\mathrm{ex}}=280 \mathrm{~nm}\right)$ for 1,3-bitl respectively. After metallization of these ligands with $\mathrm{Cd}(\mathrm{II}) / \mathrm{Zn}$ (II) atom, the main emission peaks occur at $375 \mathrm{~nm}\left(\lambda_{\mathrm{ex}}=275 \mathrm{~nm}\right)$ for $\mathbf{1}$, $369 \mathrm{~nm}\left(\lambda_{\text {ex }}=270 \mathrm{~nm}\right)$ for $2,376 \mathrm{~nm}\left(\lambda_{\text {ex }}=265 \mathrm{~nm}\right)$ for 3 , and $383 \mathrm{~nm}\left(\lambda_{\text {ex }}=255 \mathrm{~nm}\right)$ for 4 . In comparison to the free ligands, the emission peaks of 1-4 are close to imidazol ligands, so the emission bands of these complexes can probably be attributed to the $\mathrm{N}$-donor ligand fluorescence emission. Compared to the free $\mathrm{N}$-donor ligand, their peaks are blue-shifted by $5 \mathrm{~nm}, 2 \mathrm{~nm}$, $2 \mathrm{~nm}$ and $2 \mathrm{~nm}$, respectively. These emissions are neither metalto-ligand charge transfer (MLCT) nor ligand-to-metal charge transfer (LMCT) in nature, since Cd(II) and $\mathrm{Zn}$ (II) ions are difficult to oxidize or reduce due to their $\mathrm{d}^{10}$ configuration. ${ }^{31}$ The photoluminescent of 1-4 may originate from the intraligand $\pi^{*}-\pi$ or $\pi^{*}-\mathrm{n}$ transition since similar emissions were also observed for the ligands themselves. The emission discrepancy of these compounds is probably due to the differences of organic ligands and coordination environments of central metal ions, which have a close relationship to the photoluminescence behavior. ${ }^{32}$ As shown in Fig. 6a, with the maximum emission peaks of 1-4 are mainly centered at 375 , 369, 376 and $383 \mathrm{~nm}$, respectively, and bright blue, blue, blue and blue fluorescence are found by visual observation at the optimum excitation. Their chromaticity coordinates (1-4) are (0.1585, 0.0221), (0.1441, 0.0486), (0.1428, 0.0518) and (0.1492, 0.0386) (Fig. 6b).

As we know that the luminescence characteristic of PLCCs is closely related to their structures. ${ }^{33}$ The size of the metal, the 
(a)

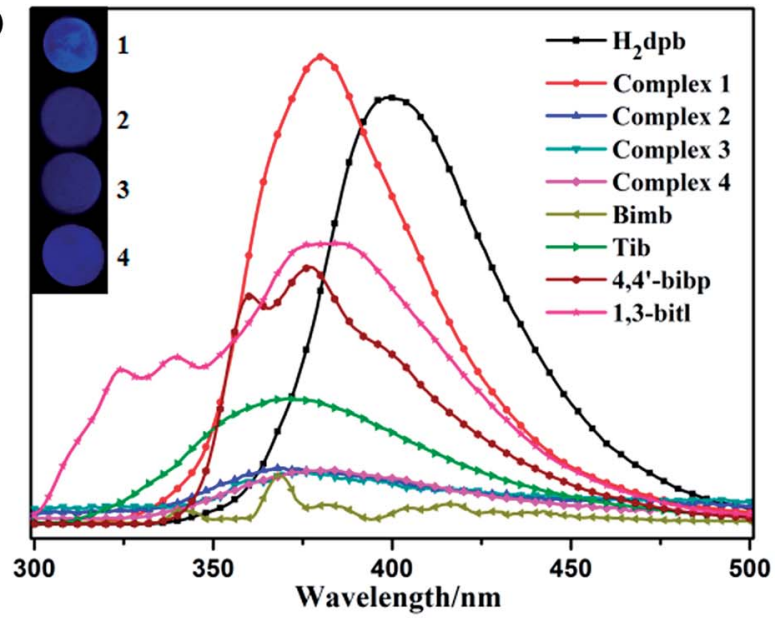

(b)

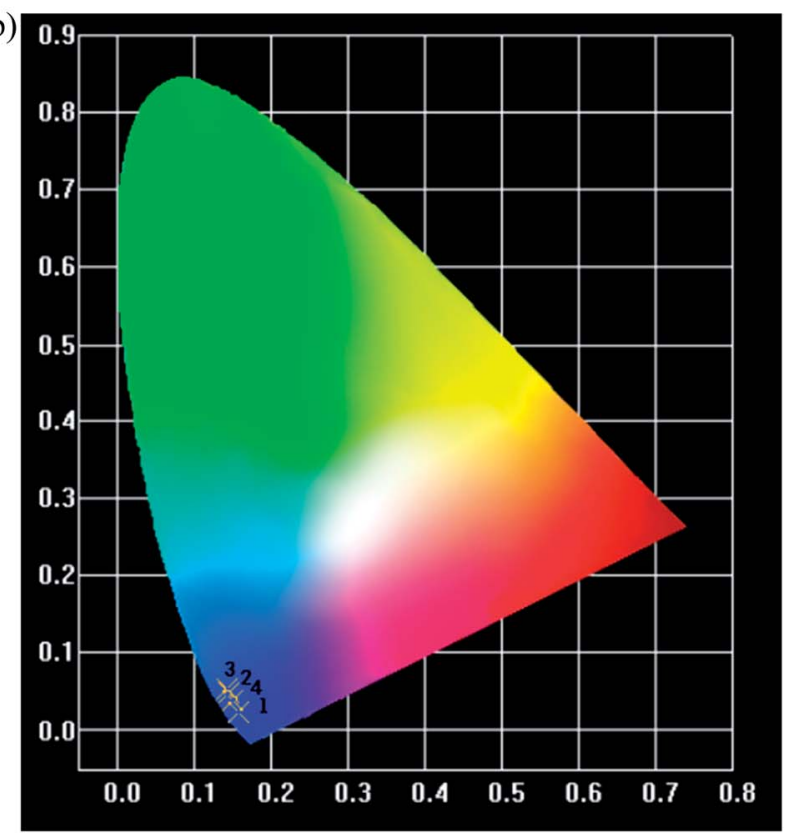

Fig. 6 (a) Photoluminescence of CPs 1-4 at room temperature in the solid state. The inset shows the relative fluorescence images. (b) $\mathrm{CIE}$ chromaticity diagrams of 1-4.

structure of the secondary building units (SBUs) and the orientation of the linkers all affect the emission properties of the material. ${ }^{34}$ Compounds 1-4 contain the same linker $\left(\mathrm{H}_{2} \mathrm{dpb}\right)$ in different coordination modes and geometries, allowing comparative study of their photoluminescence diversity. Here we observed that compounds 2 (blue), 3 (blue) and 4 (blue) display similar emission character, which is different from that of 1 (bright blue). The different visual fluorescence maybe attributed to the various structures of four complexes (1 (3D), 2 (2D), 3 (1D) and 4 (2D)).

\section{$\mathrm{Fe}^{3+} / \mathrm{Cu}^{2+}$-sensing properties}

Currently, the luminescent MOFs have great advantages in the ion detection and separation. ${ }^{35}$ Among the metal cations, the $\mathrm{Fe}^{3+} / \mathrm{Cu}^{2+}$ cations are the most necessary elements involved in biochemical processes in humans. ${ }^{36}$ Based on the strong luminescence and good water stabilities of 1-4, the sensing properties of complexes on metal cations were investigated. In order to examine their sensing abilities, the luminescence spectra of 1-4 $(3 \mathrm{mg})$ dispersed in water solutions $(3 \mathrm{~mL})$ of $0.01 \mathrm{M}\left(\mathrm{mol} \mathrm{L}^{-1}\right) \mathrm{AgNO}_{3}$ or $\mathrm{MCl}_{x}\left(\mathrm{M}=\mathrm{Na}^{+}, \mathrm{K}^{+}, \mathrm{Ca}^{2+}, \mathrm{Mg}^{2+}\right.$, $\mathrm{Cd}^{2+}, \mathrm{Mn}^{2+}, \mathrm{Co}^{2+}, \mathrm{Zn}^{2+}, \mathrm{Ni}^{2+}, \mathrm{Cu}^{2+}, \mathrm{Fe}^{3+}$ ) were studied. Each suspension solution was sonicated in the dark for $30 \mathrm{~min}$ before fluorescence testing. As can be seen in Fig. 7, complexes 2 and 3 exhibit the obvious luminescence quenching when $\mathrm{Fe}^{3+}$ ions were loaded, whereas other metal ions exhibit no quenching effects. Meanwhile, complex 1 also show luminescence quenching when $\mathrm{Ag}^{+}, \mathrm{Cu}^{2+}, \mathrm{Fe}^{3+}, \mathrm{Ni}^{2+}$ and other ions were added. Interestingly, the $\mathrm{Cu}^{2+}$ ions can bring pronounced complete quenching in $\mathbf{4}$, and the $\mathrm{Fe}^{3+}$ ions do not exhibit the obvious luminescence quenching. Those results demonstrate that compounds 2 and 3 could be highly effective and selective luminescent sensors for $\mathrm{Fe}^{3+}$ ions, and complex 4 could be highly effective and selective luminescent sensors for $\mathrm{Cu}^{2+}$ ions. It is generally accepted that the $\mathrm{N}$ atoms in the complexes can donate their lone-pair of electrons to the $\mathrm{Fe}^{3+} / \mathrm{Cu}^{2+}$ cation, which can form electron-deficient regions and act as acceptors. When under light, the luminophore in the complex can become electron donors. The energy migrations occur in case of the electrons transferred from luminophores to acceptors $\left(\mathrm{Fe}^{3+} / \mathrm{Cu}^{2+}\right)$, which leading to the fluorescence quenching. ${ }^{37,38}$

For further examining the sensitivity of luminescence quenching, the concentration-dependent studies were carried out in the presence of $\mathrm{Fe}^{3+}$ (in 2 and 3 ) $/ \mathrm{Cu}^{2+}$ (in 4 ) with different concentrations. As shown in Fig. 8, the emission intensities 2-4 decreased gradually with increasing of $\mathrm{Fe}^{3+}$ (in 2 and 3 ) $/ \mathrm{Cu}^{2+}$ (in 4) from 0 to $5 \times 10^{-3} \mathrm{M} .{ }^{39}$ The Stern-Volmer equation $\left(I_{0} / I-1=\right.$ $\left.K_{\mathrm{sv}} C_{[\mathrm{M}]}\right]$ can be used to calculated the corresponding quenching coefficient, in which the values $I_{0}$ and $I$ are the luminescent intensities of 2-4 without and with addition of $\mathrm{Fe}^{3+} / \mathrm{Cu}^{2+}$, respectively, $K_{\mathrm{sv}}$ is the quenching constant, and $C_{[\mathrm{M}]}$ is the concentration of metal ions. ${ }^{40}$ Based on the luminescent data, the $K_{\mathrm{Sv}}$ were $1.212 \times 10^{4}$ for $2,9.383 \times 10^{3}$ for 3 and $4.894 \times 10^{4}$ for 4 , respectively. The $K_{\mathrm{sv}}$ value can be used to evaluate the metal ions selective and sensitive sensing of complexes. The higher $K_{\mathrm{sv}}$ of 2 demonstrates that the luminescent quenching effect for $\mathrm{Fe}^{3+}$ ions of $\mathbf{2}$ are more sensitive than 3. Meanwhile, the luminescent quenching effect for $\mathrm{Cu}^{2+}$ ions of $\mathbf{4}$ are more sensitive than 2 and 3.

The above luminescent studies indicate that 2 and 3 could selectively sense the exoteric $\mathrm{Fe}^{3+}$ through the luminescent quenching, and 4 could be highly effective and selective luminescent sensors for $\mathrm{Cu}^{2+}$ ions. The PXRD patterns of the $\mathrm{Fe}^{3+} /$ $\mathrm{Cu}^{2+}$ loaded 2-4 were nearly corresponded with the original samples (Fig. S5†). The results show that their basic frameworks are stable after loaded metal ions.

\section{$\mathrm{Cr}_{2} \mathrm{O}_{7}{ }^{2-}$-sensing properties}

Encourage by the metal ions' high selective and sensitive of 1-4, their sensing of trace anions in aqueous were investigated 

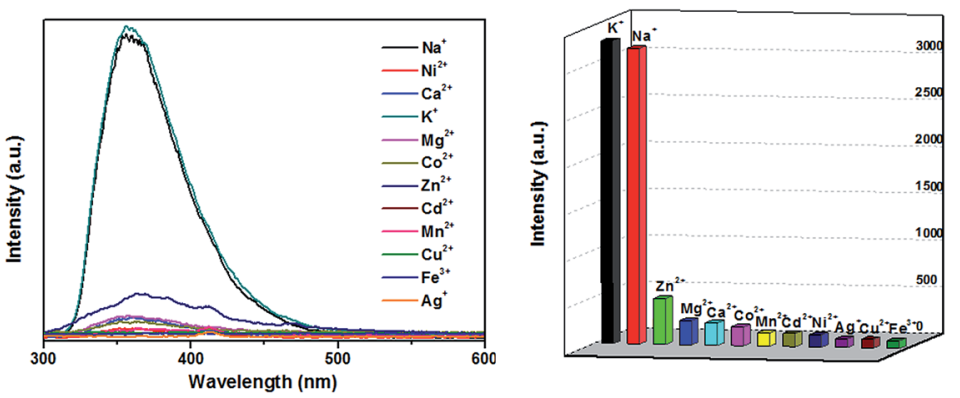

(a)
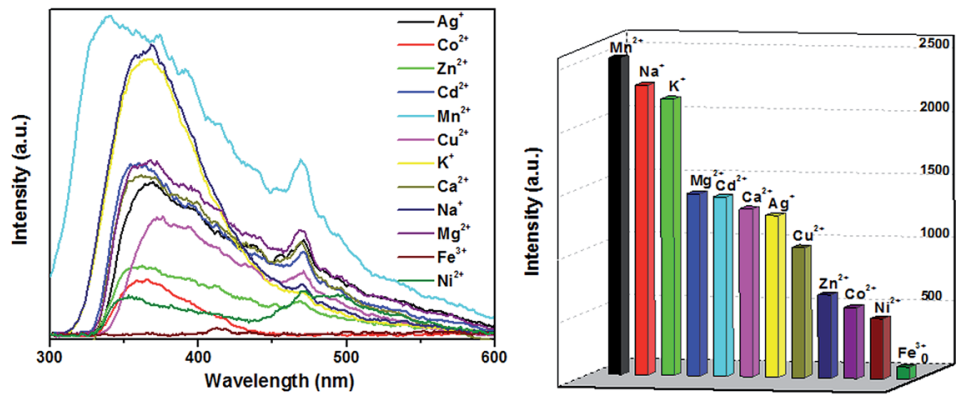

(b)
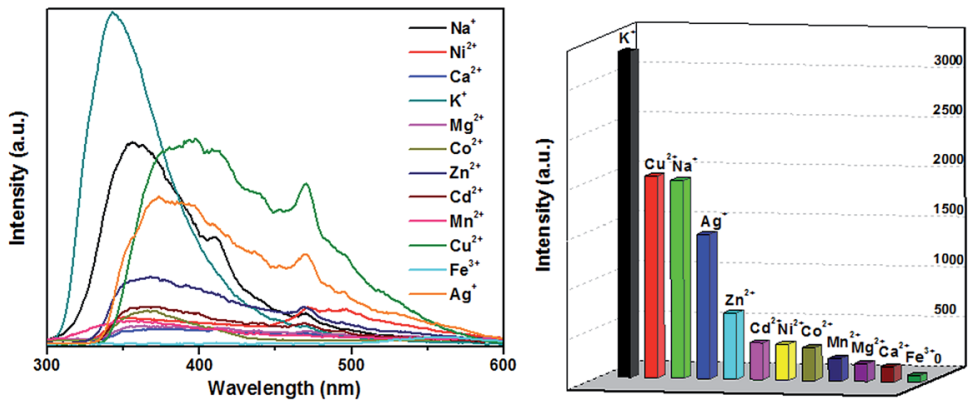

(c)
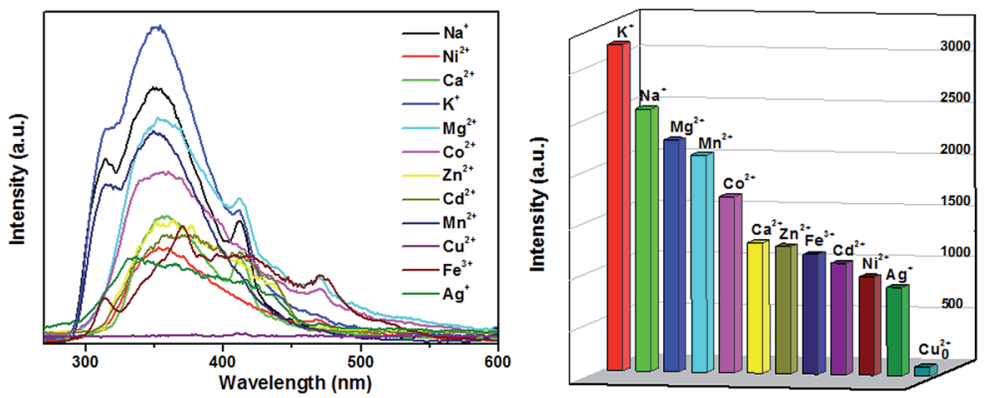

(d)

Fig. 7 Emission spectra and intensities for 1 (a), 2 (b), 3 (c) and 4 (d) in solutions of different metal cations.

through the way that polymers 1-4 $(3 \mathrm{mg})$ were soaked in an aqueous solution ( $3 \mathrm{~mL}$ ) of $0.01 \mathrm{M} \mathrm{K}_{2} \mathrm{CO}_{3}, \mathrm{~K}_{2} \mathrm{Cr}_{2} \mathrm{O}_{7}, \mathrm{~K}_{2} \mathrm{~S}_{2} \mathrm{O}_{8}$, $\mathrm{K}_{2} \mathrm{SO}_{4}, \mathrm{KSCN}, \mathrm{CH}_{3} \mathrm{COOK}, \mathrm{KCl}, \mathrm{KClO}_{3}, \mathrm{KIO}_{3}, \mathrm{KNO}_{3}, \mathrm{KOH}$ and
$\mathrm{KH}_{2} \mathrm{PO}_{4}$. After the polymer-anion suspensions were sonicated in the dark for $30 \mathrm{~min}$, the photoluminescent spectra were investigated. As shown in Fig. 9, the four titled complexes with other 

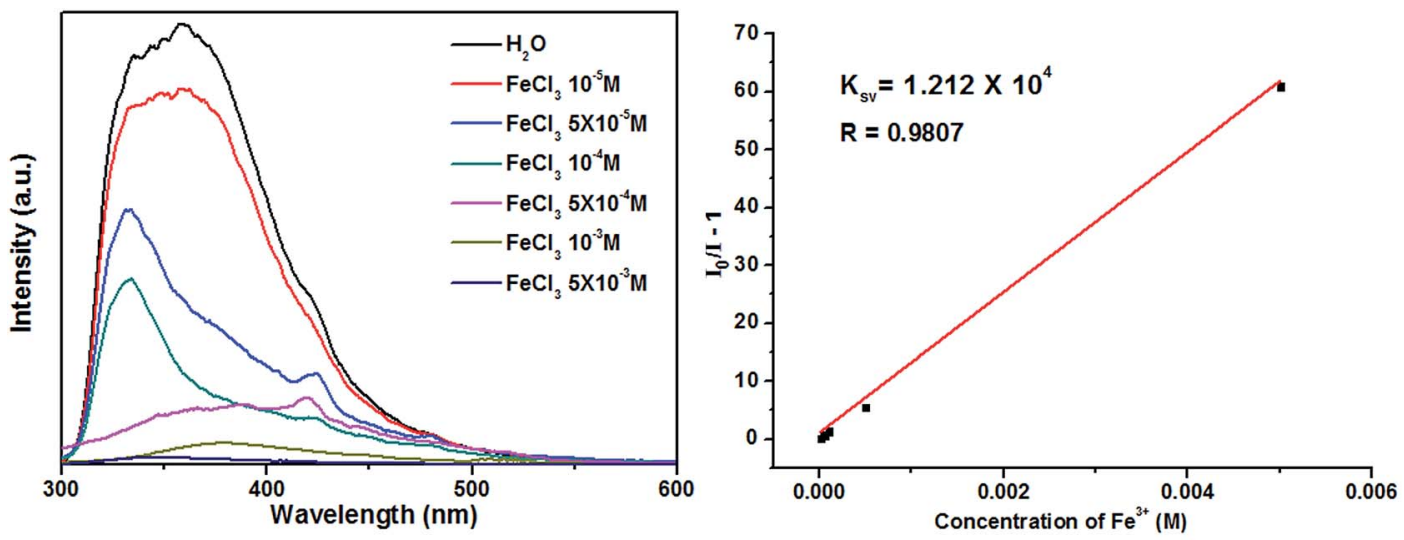

(a)
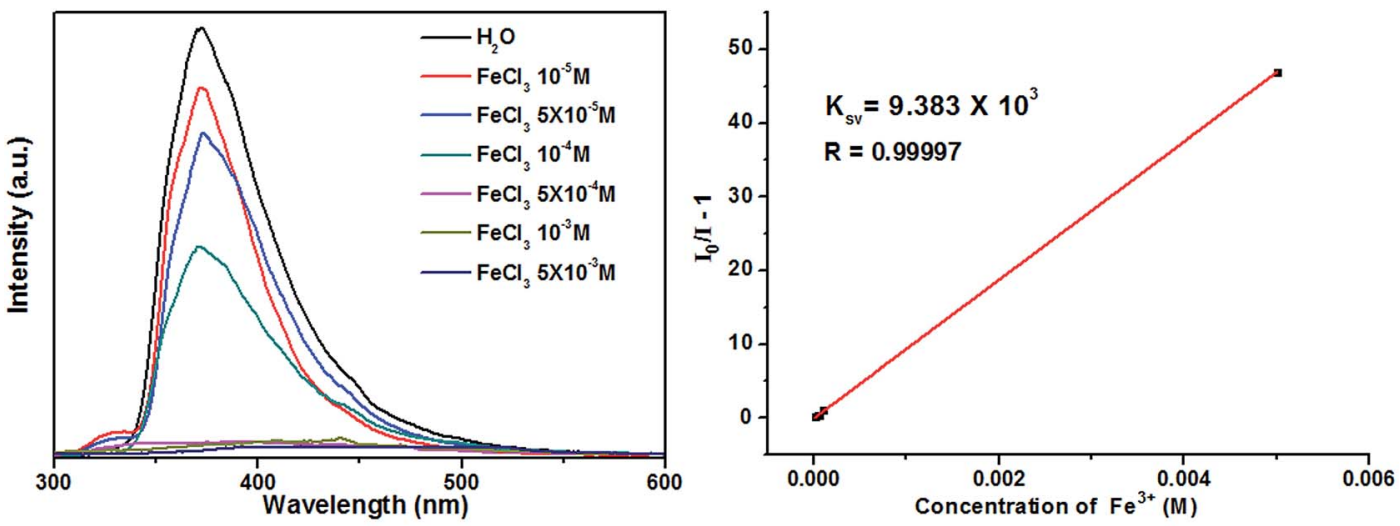

(b)
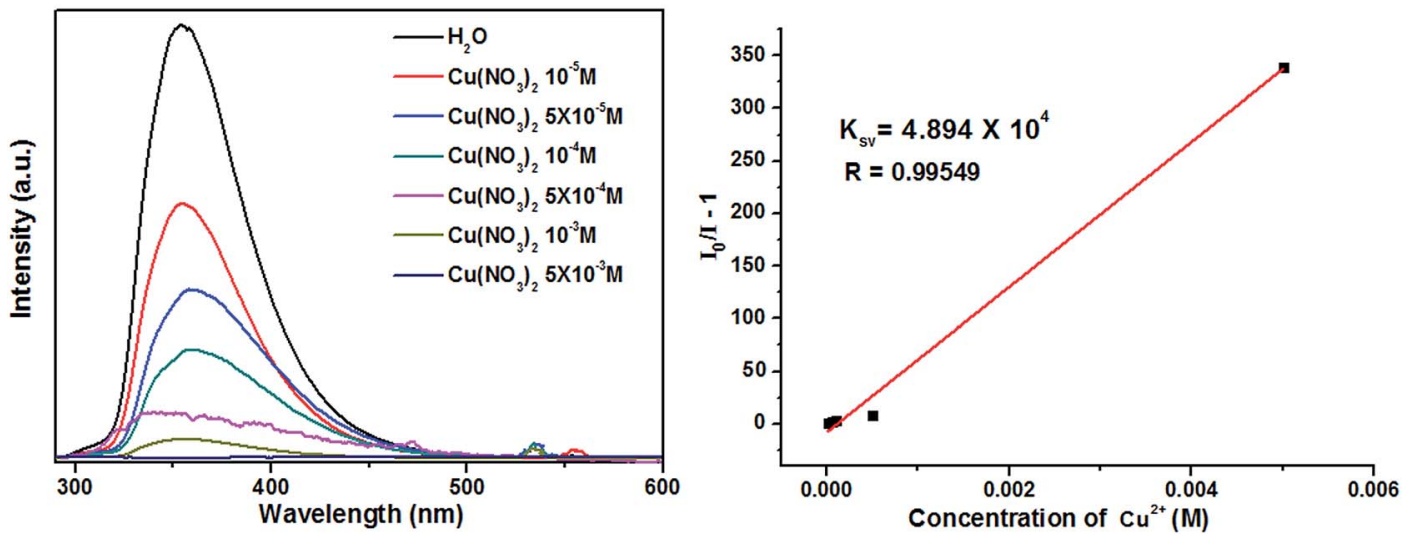

(c)

Fig. 8 Emission spectra and linear relationships for 2 (a), 3 (b) and 4 (c) in aqueous solutions of different $\mathrm{Fe}^{3+} / \mathrm{Cu}^{2+}$ concentrations.

anions do not exhibit the obvious luminescence quenching except $\mathrm{Cr}_{2} \mathrm{O}_{7}{ }^{2-}$, which exhibited an obviously quenching effect. The absorption bands of the $\mathrm{Cr}_{2} \mathrm{O}_{7}{ }^{2-}$ (two wide absorption bands from 230 to $413 \mathrm{~nm})^{41}$ almost cover the whole ranges of absorption bands that arise from complexes 1-4 (320-450 nm). Therefore, the luminescence quenching may be caused by the 

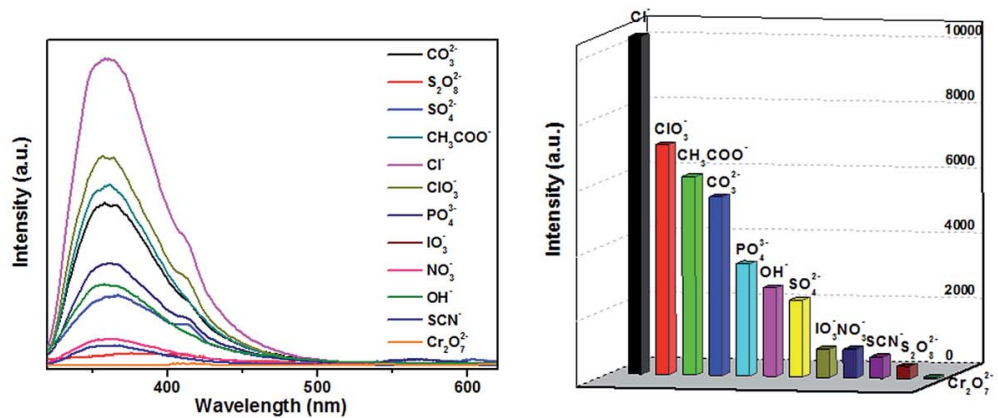

(a)
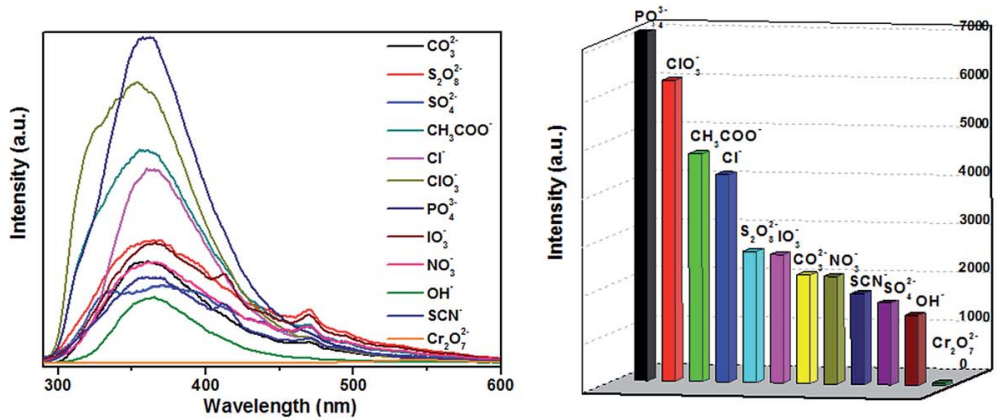

(b)
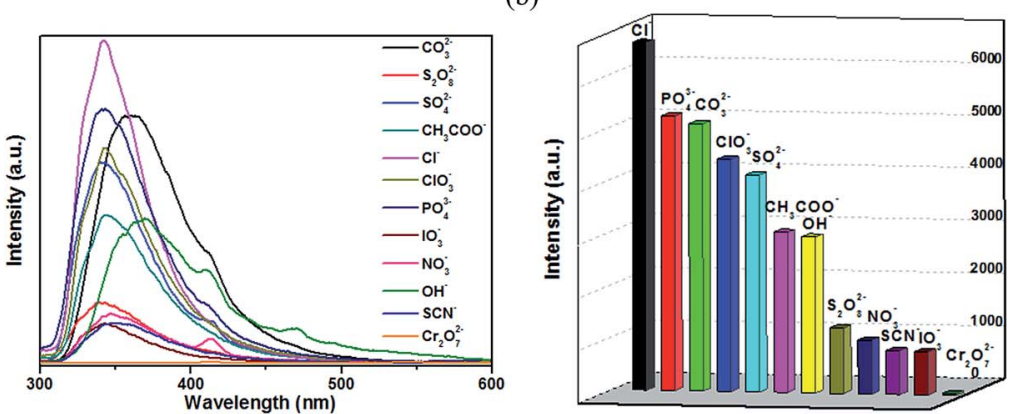

(c)
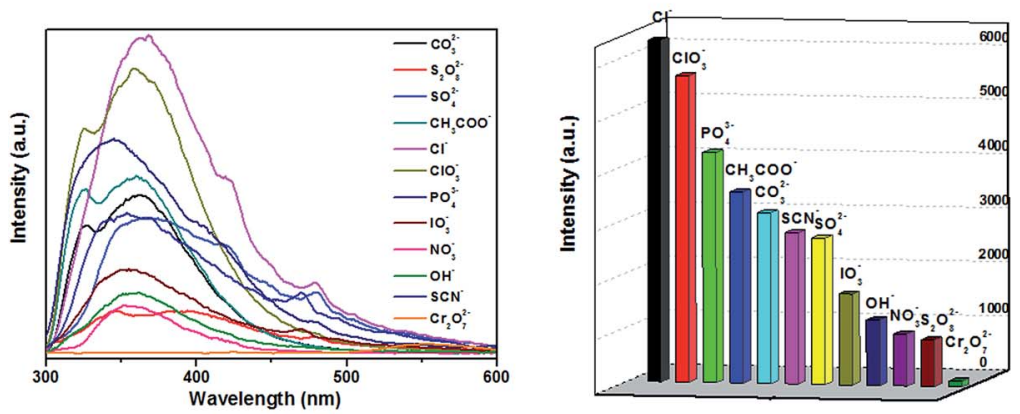

(d)

Fig. 9 Emission spectra and intensities for 1 (a), 2 (b), 3 (c) and 4 (d) in solutions of different anions.

competition of excitation energy between the complexes and $\mathrm{Cr}_{2} \mathrm{O}_{7}{ }^{2-} .^{38}$ The PXRD results reveal that four titled compounds were stable after sensing $\mathrm{Cr}_{2} \mathrm{O}_{7}{ }^{2-}$ (Fig. S5 $\dagger$ ).
As shown in Fig. 10, the luminescence intensities of 1-4 are gradually decreased with increasing $\mathrm{Cr}_{2} \mathrm{O}_{7}{ }^{2-}$ concentrations, and the luminescence intensities are almost completely 

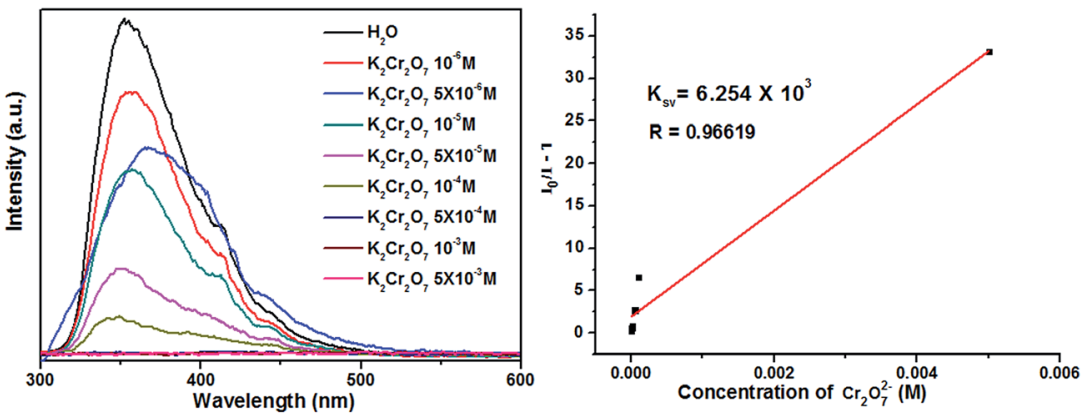

(a)
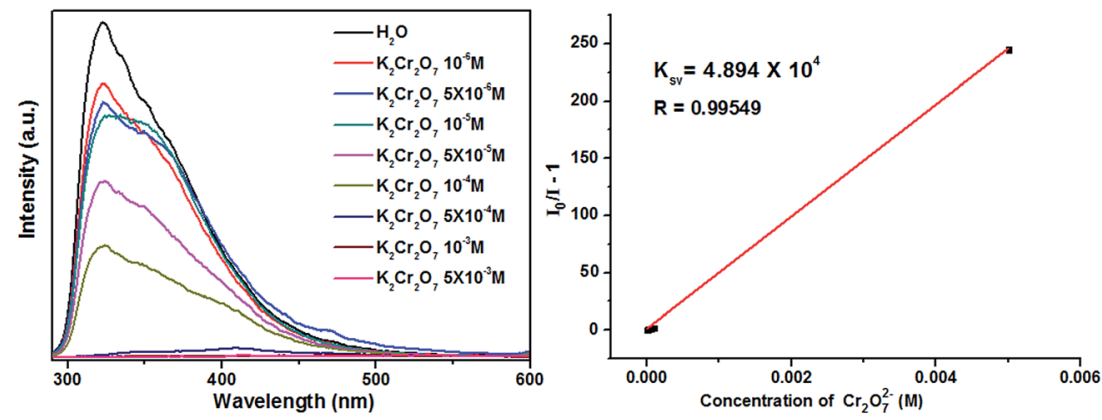

(b)
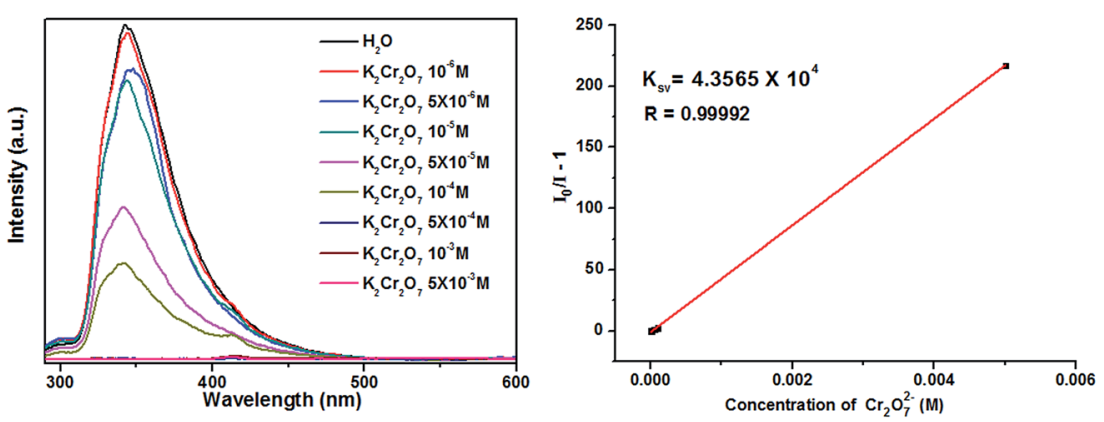

(c)
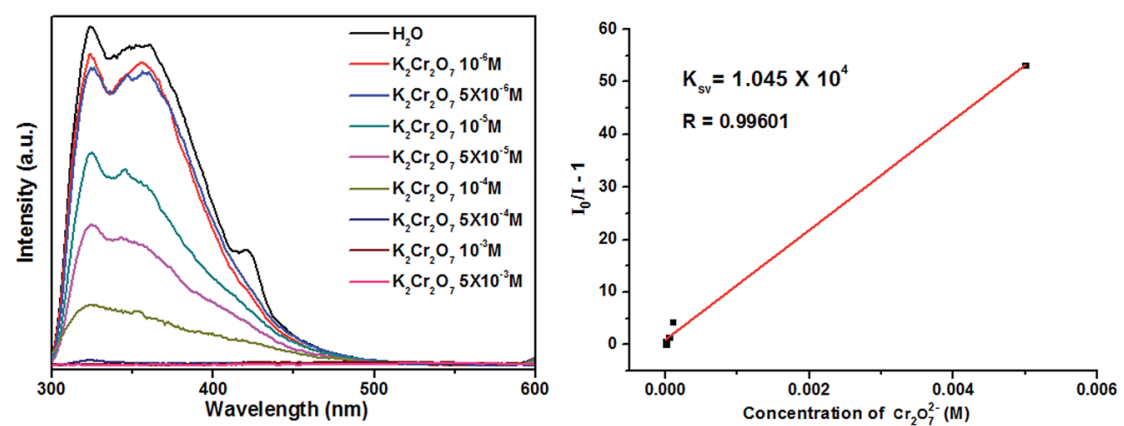

(d)

Fig. 10 Emission spectra and linear relationships for 1 (a), 2 (b), 3 (c) and 4 (d) in aqueous solutions of different $\mathrm{Cr}_{2} \mathrm{O}_{7}{ }^{2-}$ concentrations.

quenched at the concentrations of $5 \times 10^{-4} \mathrm{M}$. The $K_{\mathrm{sv}}$ values calculated by Stern-Volmer equation are $6.254 \times 10^{3}, 4.894 \times$ $10^{4}, 4.357 \times 10^{4}$ and $1.045 \times 10^{4}$, respectively. Thus, the complexes 2-4 are much more sensitive than $\mathbf{1}$ in detecting $\mathrm{Cr}_{2} \mathrm{O}_{7}{ }^{2-}$. Moreover, complexes 2-4 show high sensitivities in sensing $\mathrm{Cr}_{2} \mathrm{O}_{7}{ }^{2-}$ noxious anion compared with other reported 

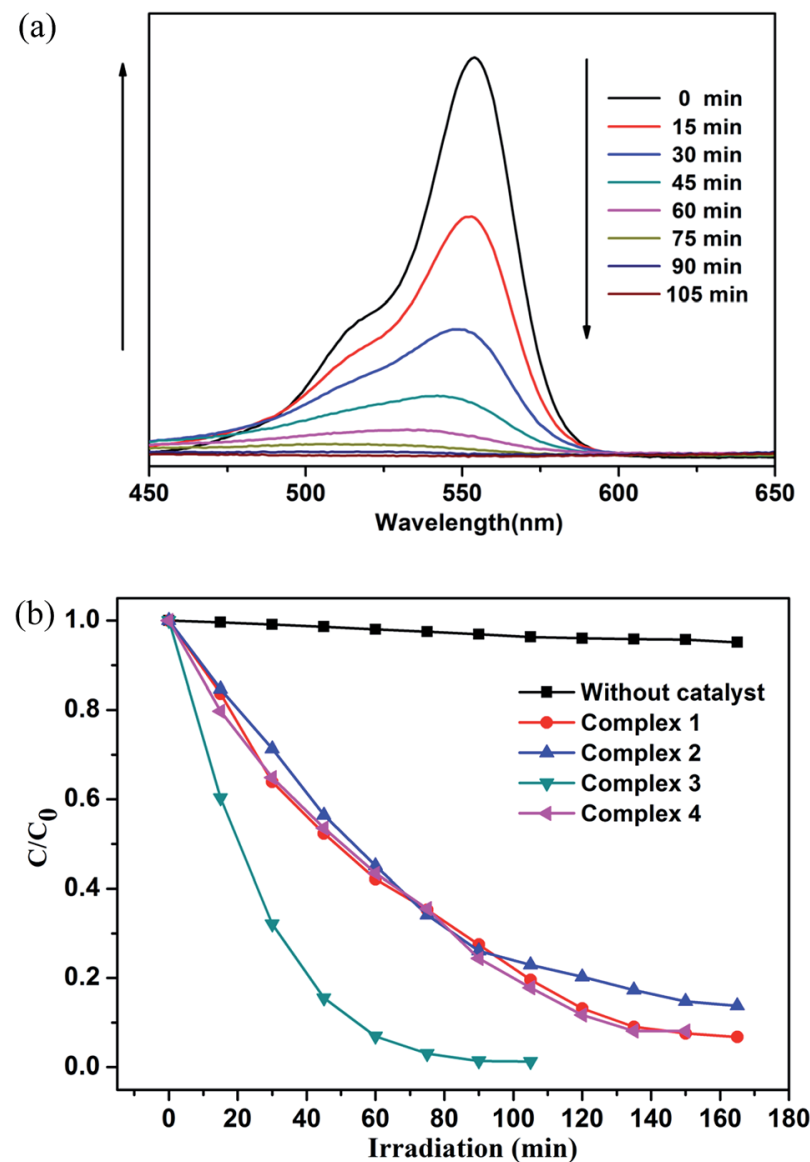

Fig. 11 (a) Absorption spectra of the RhB solution in the presence of complex 3. (b) Plots of concentration ratios of $\mathrm{RhB}\left(c / \mathrm{c}_{0}\right)$ against irradiation time ( $\mathrm{min}$ ) in the presence of complexes 1-4 and without any catalyst during the decomposition reaction under UV irradiation.

CPs. ${ }^{41-43}$ The high sensitivity indicates that complexes 2-4 may be a good candidate for the sensing of $\mathrm{Cr}_{2} \mathrm{O}_{7}^{2-}$ anion in industry.

\section{Photocatalysis properties}

Photocatalysts have attracted much attention due to their potential applications in purifying water by thoroughly decomposing organic compounds. ${ }^{44}$ It is well known that rhodamine $\mathrm{B}(\mathrm{RhB})$ and methylene blue (MB) are the most common organic dyes in waste water, and some MOFs show photocatalytic activity in the degradation of organic dyes under UV irradiation by oxidation of organic materials. ${ }^{45}$ Here, we investigated the photocatalytic ability of the title complexes (14) towards the degradation of $\mathrm{RhB}$ and $\mathrm{MB}$ under UV irradiation. The photocatalytic experiments were performed by the following process: ${ }^{46} 20 \mathrm{mg}$ of $\mathbf{1}, 2,3$ and $\mathbf{4}$ was dispersed in 100 $\mathrm{mL}$ aqueous solution of $\mathrm{RhB}\left(6 \mathrm{mg} \mathrm{L}^{-1}\right)$ or $\mathrm{MB}\left(6 \mathrm{mg} \mathrm{L}^{-1}\right)$, respectively. For the adsorption-desorption equilibrium, the mixture was stirred in the dark for $30 \mathrm{~min}$ before turning on the $\mathrm{Hg}$ lamp (125 W). After centrifugation of the sample, the transparent solution was tested under UV measurement. ${ }^{47}$

The photocatalytic activities of 1-4 in RhB solution are shown in Fig. 11a and S6. $\dagger$ From the Fig. 11a and S6, $\dagger$ we can (a)

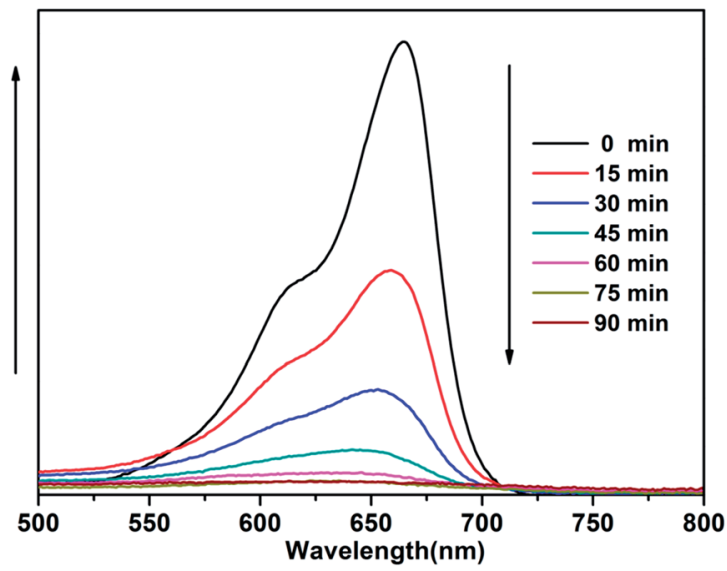

(b)

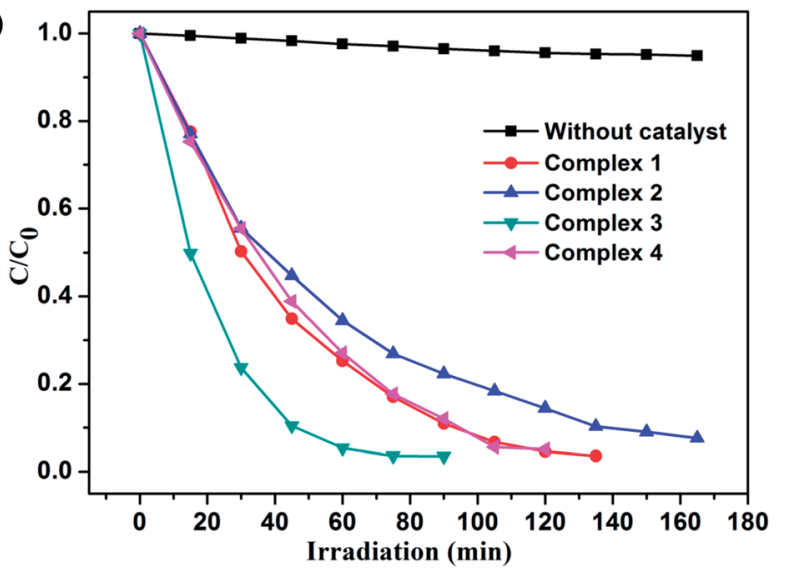

Fig. 12 (a) Absorption spectra of the MB solution in the presence of complex 3. (b) Plots of concentration ratios of $M B\left(c / c_{0}\right)$ against irradiation time ( $\mathrm{min}$ ) in the presence of complexes 1-4 and without any catalyst during the decomposition reaction under UV irradiation.

found that the absorbance peaks of RhB decreased obviously with different photocatalytic efficiency after the compounds were added. Moreover, the concentration ratios of $\mathrm{RhB}\left(c / c_{0}\right)$ against irradiation time ( $\mathrm{min}$ ) in the presence of the complexes 1-4 were plotted, with $c_{0}$ representing the initial concentration of $\mathrm{RhB}$ after magnetically stirring in the dark for $30 \mathrm{~min}$ (Fig. 11b). For complexes 1-4, the RhB solution has been taken out every $15 \mathrm{~min}$, but the photocatalytic efficiency is different. The degradation ratios of RhB are $90.2 \%$ for $1,82.7 \%$ for 2 and 95.1\% for 4 after 135 min of UV irradiation except complex 3 ( $97.1 \%$ and $98.7 \%$ after 75 and $90 \mathrm{~min}$ ), and the remarkable photocatalytic activity is $\mathbf{3}>\mathbf{4}>\mathbf{1}>\mathbf{2}$. Meanwhile, all the RhB degradation ratios of control experiments did not surpass $30 \%$ and nearly cease after $150 \mathrm{~min}(91.8 \%$ for $\mathbf{1}, 85.3 \%$ for $2,98.7 \%$ for 3 and $95.1 \%$ for 4 ) under UV irradiation.

As shown in Fig. 12 and $\mathrm{S} 7, \uparrow$ the degradation ratios of MB are $93.2 \%$ for $\mathbf{1}, 85.6 \%$ for 2 and $94.9 \%$ for 4 after $120 \mathrm{~min}$ of UV irradiation except complex 3 (96.5\% after $75 \mathrm{~min})$. The MB degradation ratios of control experiments did not surpass $30 \%$ and nearly cease after 150 min under UV irradiation. From photocatalytic degradation results, we found that the complex 3 much better than the complex 1, 2 and 4 in RhB and MB. 


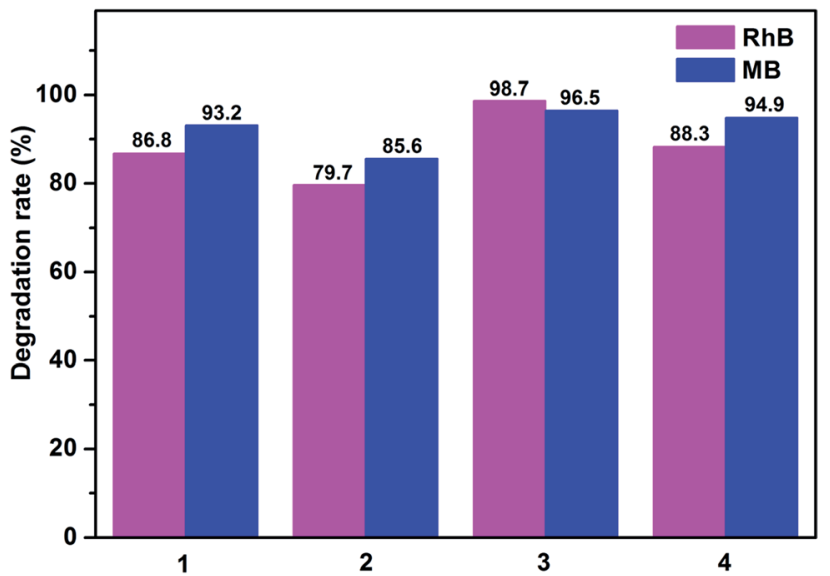

Fig. 13 Degradation rates of the RhB and MB solutions in the presence of complexes 1-4.

Moreover, the photocatalytic activity of the complex 1, 2, 3 and 4 is better in MB solution compared with RhB solution in $120 \mathrm{~min}$ (Fig. 13).

Fig. $11 \mathrm{~b}$ and $12 \mathrm{~b}$ show that the titled complexes have good photocatalytic activities for the photodegradation of RhB and MB under UV irradiation, and the degradation activity $3>4>1>$ 2, which corresponding with the optical band gaps ( $E_{\mathrm{g}}$ values: $2.70 \mathrm{eV}$ for $\mathbf{1}, 2.74 \mathrm{eV}$ for $2,2.28 \mathrm{eV}$ for 3 and $2.59 \mathrm{eV}$ for 4$)$. As we know, for complex structures, the numbers of the coordinated water molecules, the coordination environments of the central metals, the extent of the conjugation ${ }^{48}$ and optical band gap could influence the photocatalytic activities. Therefore, it can be surmised that the low optical band gap and coordination environments of $\mathrm{Zn}$ (II) (four-coordination) of 3 aided in the transport of excited holes/electrons to the surface to initiate the photocatalytic decomposition reaction. Moreover, all of the titled $\mathrm{d}^{10}$ compounds (1-4) show a better photocatalytic activity compared with reported similar $\mathrm{Cd}(\mathrm{II}) / \mathrm{Zn}$ (II) $\mathrm{CPs}^{\mathbf{2 8 , 4 9}}$ in the degradation of MB under the same condition (Table S5 $\dagger$ ). Thus, complex 3 may be candidates for photocatalytic activity in the degradation of some organic dyes.

When the complex is exposed under UV light, the $2 p$ bonding orbital of the oxygen and/or nitrogen atom which in metal complex could transfer an electron from the highest occupied molecular to the lowest unoccupied molecular orbital (an empty metal orbital). Then the water molecule would captured one electron for the stable of highest occupied molecular orbital. Meanwhile, the water molecule was oxygenated into the ${ }^{\circ} \mathrm{OH}$ radical. The ${ }^{\circ} \mathrm{OH}$ active species could decompose $\mathrm{RhB}$ and $\mathrm{MB}$ effectively to complete the photocatalytic process. ${ }^{50}$ Meanwhile, the PXRD results revealed that four $\mathrm{Cd}(\mathrm{II}) / \mathrm{Zn}$ (II) compounds were stable in degradation process, as shown in Fig. S8. $\dagger$

\section{Conclusions}

In summary, four LCPs were synthesized based on "V"-shaped 3,5-di(4'-carboxyl-phenyl)benzene acid $\left(\mathrm{H}_{2} \mathrm{dpb}\right)$ and four different imidazole bridging linkers (bimb, tib, 4,4'-bibp and 1,3-bitl) under hydrothermal conditions, with the final packing structures exhibiting a systematic variation of architectures from 1D chains based supramolecular to 3D interpenetrated frameworks. These results reveal that nature of the bridging $\mathrm{N}$ donor linkers have significant effects on the $\mathrm{H}_{2} \mathrm{dpb}$ coordination modes and the final packing structures. Moreover, the luminescent sensing of metal cations and anions through fluorescence quenching were investigated systematically and quantitatively. The results demonstrate that 2 and 3 display high sensitive and selective luminescent sensing towards $\mathrm{Fe}^{3+}$ ion, and 4 display high sensitive and selective luminescent sensing towards $\mathrm{Cu}^{2+}$ ion. Both 1-4 can work as high sensitive sensors to $\mathrm{Cr}_{2} \mathrm{O}_{7}{ }^{2-}$ by luminescent quenching. And the photocatalytic studies indicate that complex 3 is good candidates for the photocatalytic degradation of rhodamine $\mathrm{B}(\mathrm{RhB})$ and methylene blue (MB).

\section{Acknowledgements}

This research was supported by the National Natural Science Foundation of China to C. F. Bi (No. 21371161), the Specialized Research Fund for the Doctoral Program of Higher Education of China (No. 20120132110015).

\section{References}

1 (a) Y. J. Cui, Y. F. Yue, G. D. Qian and B. L. Chen, Chem. Rev., 2012, 2, 703; (b) H. Yang, F. Wang, Y. X. Tan, T. H. Li and J. Zhang, Chem.-Asian J., 2012, 7, 1069; (c) M. J. Sie, Y. J. Chang, P. W. Cheng, P. T. Kuo, C. W. Yeh, C. F. Cheng, J. D. Chen and J. C. Wang, CrystEngComm, 2012, 14, 5505; (d) G. M. Sun, Y. M. Song, Y. Liu, X. Z. Tian, H. X. Huang, Y. Zhu, Z. J. Yuan, X. F. Feng, M. B. Luo, S. J. Liu, W. Y. Xu and F. Luo, CrystEngComm, 2012, 14, 5714; (e) Y. W. Li, H. Ma, Y. Q. Chen, K. H. He, Z. X. Li and X. H. Bu, Cryst. Growth Des., 2012, 12, 189; (f) Z. Y. Du, H. B. Xu and J. G. Mao, Inorg. Chem., 2006, 45, 9780; $(g)$ M. D. Allendorf, C. A. Bauer, R. K. Bhakta and R. J. T. Houk, Chem. Soc. Rev., 2009, 38, 1330.

2 (a) M. Yoon, R. Srirambalaji and K. Kim, Chem. Rev., 2012, 112, 1196; (b) J. Lee, O. K. Farha, J. Roberts, K. A. Scheidt, S. T. Nguyen and J. T. Hupp, Chem. Soc. Rev., 2009, 38, 1450; (c) M. B. Lalonde, O. K. Farha, K. A. Scheidt and J. T. Hupp, ACS Catal., 2012, 2, 1550; (d) K. S. Jeong, Y. B. Go, S. M. Shin, S. J. Lee, J. Kim, O. M. Yaghi and N. Jeong, Chem. Sci., 2011, 2, 877.

3 (a) J. Li, J. Tao, R. B. Huang and L. S. Zheng, Inorg. Chem., 2012, 51, 5988; (b) H. L. Wang, D. P. Zhang, D. F. Sun, Y. T. Chen, K. Wang, Z. H. Ni, L. J. Tian and J. Z. Jiang, CrystEngComm, 2010, 12, 1096; (c) M. Kurmoo, Chem. Soc. Rev., 2009, 38, 1353; (d) L. H. Jia, R. Y. Li, Z. M. Duan, S. D. Jiang, B. W. Wang, Z. M. Wang and S. Gao, Inorg. Chem., 2011, 50, 144; (e) S. Y. Qian, H. Zhou, A. H. Yuan and Y. Song, Cryst. Growth Des., 2011, 11, 5676.

4 (a) L. J. Murray, M. Dinca and J. R. Long, Chem. Soc. Rev., 2009, 38, 1294; (b) H. Uehara, S. Diring, S. Furukawa, Z. Kalay, M. Tsotsalas, M. Nakahama, K. Hirai, M. Kondo, 
O. Sakata and S. Kitagawa, J. Am. Chem. Soc., 2011, 133, 11932; (c) Y. Kang, F. Wang, J. Zhang and X. Bu, J. Am. Chem. Soc., 2012, 134, 117881; (d) J. R. Li, R. J. Kuppler and H. C. Zhou, Chem. Soc. Rev., 2009, 38, 1477; (e) C. T. He, J. Y. Tian, S. Y. Liu, G. F. Ouyang, J. P. Zhang and X. M. Chen, Chem. Sci., 2013, 4, 351.

5 (a) G. Férey, Chem. Soc. Rev., 2008, 37, 191; (b) H. X. Zhang, F. Wang, Y. X. Tian, Y. Kang and J. Zhang, J. Mater. Chem., 2012, 22, 16288; (c) J. R. Li, J. Sculley and H. C. Zhou, Chem. Rev., 2012, 112, 869; (d) H. L. Jiang, Y. Tatsu, Z. H. Lu and Q. Xu, J. Am. Chem. Soc., 2010, 132, 5586.

6 (a) M. Yoon, K. Suh, S. Natarajan and K. Kim, Angew. Chem., Int. Ed., 2013, 52, 2688; (b) P. Ramaswamy, N. E. Wong and G. K. H. Shimizu, Chem. Soc. Rev., 2014, 43, 5913; (c) S. Horike, D. Umeyama and S. Kitagawa, Acc. Chem. Res., 2013, 46, 2376.

7 (a) F. E. Kuhn, J. L. Zuo, F. F. Biani, A. M. Santos, Y. M. Zhang, J. Zhao, A. Sandulache and E. Herdtweck, New J. Chem., 2004, 28, 43; (b) W. Lu, N. Y. Zhu and C. M. Che, J. Am. Chem. Soc., 2003, 125, 16081; (c) A. Albinati, P. Leoni, L. Marchetti and S. Rizzato, Angew. Chem., Int. Ed., 2003, 42, 5990.

8 L. Carlucci, G. Ciani and D. M. Proserpio, Coord. Chem. Rev., 2003, 246, 247.

9 L. Y. Pang, G. P. Yang, J. C. Jin, M. Kang, A. Y. Fu and Y. Y. Wang, Cryst. Growth Des., 2014, 14, 2954.

10 C. J. Watras, R. C. Back, S. Halvorsen, R. J. M. Hudson, K. A. Morrison and S. P. Wente, Sci. Total Environ., 1998, 219, 183.

11 J. Kong, N. R. Franklin, C. Zhou, M. G. Chapline, S. Peng, K. Cho and H. Dai, Science, 2000, 287, 622.

12 J. C. Jin, L. Y. Pang, G. P. Yang, L. Hou and Y. Y. Wang, Dalton Trans., 2015, 44, 17222.

13 X. Wang, T. Qin, S. S. Bao, Y. C. Zhang, X. Shen, L. M. Zheng and D. R. Zhu, J. Mater. Chem. A, 2016, 4, 16484.

14 R. Lv, J. Y. Wang, Y. P. Zhang, H. Li, L. Y. Yang, S. Y. Liao, W. Gu and X. Liu, J. Mater. Chem. A, 2016, 4, 15494.

15 (a) X. L. Wang, J. Luan, H. Y. Lin, C. Xu, G. C. Liu, J. W. Zhang and A. X. Tian, CrystEngComm, 2013, 15, 9995; (b) X. L. Wang, J. J. Huang, L. L. Liu, G. C. Liu, H. Y. Lin, J. W. Zhang, N. L. Chen and Y. Qu, CrystEngComm, 2013, 15, 1960.

16 (a) X. Lin, I. Telepeni, A. J. Blake, A. Dailly, C. M. Brown, J. M. Simmons, M. Zoppi, G. S. Walker, K. M. Thomas, T. J. Mays, P. Hubberstey, N. R. Champness and M. Schröder, J. Am. Chem. Soc., 2009, 131, 2159; (b) H. S. Choi and M. P. Suh, Angew. Chem., Int. Ed., 2009, 48, 6865; (c) B. L. Chen, N. W. Ockwig, A. R. Millward, D. S. Contreras and O. M. Yaghi, Angew. Chem., Int. Ed., 2005, 44, 4745; (d) J. Jia, X. Lin, C. Wilson, A. J. Blake, N. R. Champness, P. Hubberstey, G. Walker, E. J. Cussen and M. Schroder, Chem. Commun., 2007, 840.

17 (a) J. M. Lim, P. Kim, M. C. Yoon, J. Sung, V. Dehm, Z. J. Chen, F. Wurthner and D. Kim, Chem. Sci., 2013, 4, 388; (b) F. Guo, F. Wang, H. Yang, X. L. Zhang and J. Zhang, Inorg. Chem., 2012, 51, 9677; (c) D. R. Xiao, Y. G. Li, E. B. Wang, L. L. Fan, H. Y. An, Z. M. Su and L. Xu, Inorg. Chem., 2007, 46, 4158; (d) S. N. Wang,
R. R. Yun, Y. Q. Peng, Q. F. Zhang, J. Lu, J. M. Dou, J. F. Bai, D. C. Li and D. Q. Wang, Cryst. Growth Des., 2012, 12, 79; (e) X. M. Meng, C. B. Fan, C. F. Bi, Z. A. Zong, X. Zhang and Y. H. Fan, CrystEngComm, 2016, 18, 2901.

18 (a) V. A. Blatov, IUCr CompComm Newsletter, 2006, 7, 4; (b) V. A. Blatov, A. P. Shevchenko and V. N. Serezhkin, J. Appl. Crystallogr., 2000, 33, 1193; (c) V. A. Blatov, M. O' Keeffe and D. M. Proserpio, CrystEngComm, 2010, 12, 44.

19 O. D. Friedrichs, Program SYSTRE 1.14 beta, 2007, http:// www.gavrog.sourceforge.net/.

20 Bruker, SMART, SAINT and SADABS, Bruker AXS Inc., Madison, Wisconsin, USA, 1998.

21 G. M. Sheldrick, SHELXTL NT, version 5.1, Program for Solution and Refinement of Crystal Structures, University of GÖttingen, GÖttingen, Germany, 1997.

22 (a) K. Nakamoto, Infrared and Raman Spectra of Inorganic and Coordination Compounds, Wiley \& Sons, New York, 5th edn, 1997; (b) G. Socrates, Infrared Characteristic Group Frequencies, Wiley, New York, 1980.

23 K. Nakamoto, Infrared and Raman Spectra of Inorganic and Coordination complexes, John Wiley \& Sons, New York, 1986.

24 (a) A. L. Spek, J. Appl. Crystallogr., 2003, 36, 7; (b) A. L. Spek, PLATON, A Multipurpose Crystallographic Tool, Utrecht University, Utrecht, The Netherlands, 2002.

25 S. S. Chen, J. Fan, T. Okamura, M. S. Chen, Z. Su, W. Y. Sun and N. Ueyama, Cryst. Growth Des., 2010, 10, 812.

26 Z. H. Yan, X. W. Zhang, H. D. Pang, Y. H. Zhang, D. F. Sun and L. Wang, RSC Adv., 2014, 4, 53608.

27 (a) L. Zhang, Y. Wei, C. Wang, H. Guo and P. J. Wang, Solid State Chem., 2004, 177, 3433; (b) J. H. Liao, J. S. Juang and Y. C. Lai, Cryst. Growth Des., 2006, 6, 354; (c) Y. Xia, P. F. Wu, Y. G. Wei, Y. Wang and H. Y. Guo, Cryst. Growth Des., 2006, 6, 253.

28 W. Q. Kan, B. Liu, J. Yang, Y. Y. Liu and J. F. Ma, Cryst. Growth Des., 2012, 12, 2288.

29 H. S. Liu, Y. Q. Lan and S. L. Li, Cryst. Growth Des., 2010, 10, 5221.

30 J. Guo, J. F. Ma, B. Liu, W. Q. Kan and J. Yang, Cryst. Growth Des., 2011, 11, 3609.

31 (a) H. Y. Liu, H. Wu, J. F. Ma, Y. Y. Liu, B. Liu and J. Yang, Cryst. Growth Des., 2010, 10, 4795; (b) W. Q. Kan, Y. Y. Liu, J. Yang, Y. Y. Liu and J. F. Ma, CrystEngComm, 2011, 13, 4256; (c) H. Y. Bai, J. Yang, B. Liu, J. F. Ma, W. Q. Kan and Y. Y. Liu, CrystEngComm, 2011, 13, 5877.

32 (a) J. Yang, Q. Yue, G.-D. Li, J.-J. Cao, G.-H. Li and J.-S. Chen, Inorg. Chem., 2006, 45, 2857; (b) X.-H. Jin, C.-X. Ren, J.-K. Sun, X.-J. Zhou, L.-X. Cai and J. Zhang, Chem. Commun., 2012, 48, 10422.

33 Y. Xiao, S. H. Wang, Y. P. Zhao, F. K. Zheng and G. C. Guo, CrystEngComm, 2016, 18, 2524.

34 (a) C. A. Bauer, T. V. Timofeeva, T. B. Settersten, B. D. Patterson, V. H. Liu, B. A. Simmons and M. D. Allendorf, J. Am. Chem. Soc., 2007, 129, 7136; (b) F. P. Doty, C. A. Bauer, A. J. Skulan, P. G. Grant and M. D. Allendorf, Adv. Mater., 2009, 21, 95.

35 X. Zhao, X. H. Bu, T. Wu, S. T. Zheng, L. Wang and P. Y. Feng, Nat. Commun., 2013, 4, 2344. 
36 (a) J. F. Wang, Y. B. Li, N. G. Patel, G. Zhang, D. Zhou and Y. Pang, Chem. Commun., 2014, 50, 1225; (b) K. G. Qu, J. S. Wang, J. S. Ren and X. G. Qu, Chem.-Eur. J., 2013, 19, 7243.

37 Z. H. Xiang, C. Q. Fang, S. H. Leng and D. P. Cao, J. Mater. Chem. A, 2014, 2, 7662.

38 M. Shi, J. Yang, Y. Y. Liu and J. F. Ma, Dyes Pigm., 2016, 129, 106.

39 S. T. Zhang, J. Yang, H. Wang, Y. Y. Liu and J. F. Ma, Chem.Eur. J., 2015, 21, 15806.

40 S. W. Thomas, G. D. Joly and T. M. Swager, Chem. Rev., 2007, 107, 1339.

41 F. Y. Yi, J. P. Li, D. Wu and Z. M. Sun, Chem.-Eur. J., 2015, 21, 11475.

42 X. Li, H. Xu, F. Kong and R. Wang, Angew. Chem., Int. Ed., 2013, 52, 13769.

43 P. F. Shi, B. Zhao, G. Xiong, Y. L. Hou and P. Cheng, Chem. Commun., 2012, 48, 8231.

44 (a) B. Liu, Z. T. Yu, J. Yang, H. Wu, Y. Y. Liu and J. F. Ma, Inorg. Chem., 2011, 50, 8967; (b) H. X. Li, X. Y. Zhang, Y. N. Huo and J. Zhu, Environ. Sci. Technol., 2007, 41, 4410.
45 (a) X. Zhang, L. Fan, W. Zhang, Y. Ding, W. Fan and X. Zhao, Dalton Trans., 2013, 42, 16562; (b) X. J. Liang, X. D. Chen and J. C. Zhao, Chem. Soc. Rev., 2014, 43, 473; (c) H. Fu, Y. G. Li, Y. Liu, W. L. Chen, Q. Wu, J. X. Meng, X. L. Wang, Z. M. Zhang and E. B. Wang, Cryst. Growth Des., 2011, 11, 458; (d) W. Wang, J. Yang, W. Q. Kan and J. F. Ma, CrystEngComm, 2013, 15, 5844.

46 J. Lü, J. X. Lin, X. L. Zhao and R. Cao, Chem. Commun., 2012, 48, 669.

47 X. L. Wang, C. H. Gong, J. W. Zhang, G. C. Liu, X. M. Kan and N. Xu, CrystEngComm, 2015, 17, 4179.

48 A. K. Paul, R. Karthik and S. Natarajan, Cryst. Growth Des., 2011, 11, 5741.

49 X. L. Wang, J. Luan, H. Y. Lin, C. Xu, G. C. Liu, J. W. Zhang and A. X. Tian, CrystEngComm, 2013, 15, 9995.

50 (a) Y. Q. Chen, S. J. Liu, Y. W. Li, G. R. Li, K. H. He, Y. K. Qu, T. L. Hu and X. H. Bu, Cryst. Growth Des., 2012, 12, 5426; (b) J. X. Meng, Y. Lu, Y. G. Li, H. Fu and E. B. Wang, CrystEngComm, 2011, 13, 2479; (c) J. Guo, J. Yang, Y. Y. Liu and J. F. Ma, CrystEngComm, 2012, 14, 6609; (d) H. X. Yang, T. F. Liu, M. N. Cao, H. F. Li, S. Y. Gao and R. Cao, Chem. Commun., 2010, 46, 2429. 